\title{
Recent Advances in the Treatment of Neurological Autoimmune Disorders
}

\author{
Jagat R. Kanwar*, Bhasker Sriramoju and Rupinder K Kanwar \\ Laboratory of Immunology and Molecular Biomedical Research (LIMBR), \\ Centre for Biotechnology and Interdisciplinary Biosciences (BioDeakin), \\ Institute for Technology in Nanomedicine \& Research Innovation, \\ Deakin University Waurn Ponds, Geelong, \\ Australia
}

\section{Introduction}

Autoimmune diseases are a complex group of diseases arising because of the breakdown of narrow margin that exists between the immunity and tolerance. In simpler terms either $\mathrm{T}$ or B-cells or both are activated in the absence of a progressive infection or any other noticeable cause (Davidson \& Diamond, 2001). Unable to distinguish self from non self, the renegade immune cells pose a serious threat to self molecules leading to severe destruction. The precise mechanisms that drive this event are still unclear but, most of the studies identified that genetics, environment and infections will have a role in triggering the autoimmune attack (Smith et al., 1999). An approximate of $5 \%$ of the population in western countries are currently the victims of these diseases and in this component, a major proportion of them are females displaying a higher risk of incidence (Jacobson, 1997; Kanwar, 2005). Added to this, the general ailments of the humans like atherosclerosis and gastrointestinal disturbances are found to be associated with an autoimmune component, predisposing the risk of developing an autoimmune disease (Ross, 1990, Galperin \& Gershwin 1997). The influence of hormones cannot be neglected as preclinical studies have witnessed the role of oestrogen in the emergence of autoimmune diseases while testosterone was found to lower the risk in lupus prone mice (Sakic, 1998; Roubinian et al., 1978). Few epidemiological studies also revealed the preponderance of autoimmune diseases mediated by the nocturnal hormone, melatonin (Cutolo, 2003). In addition, cortisol levels and the secondary events like stress were also found to influence the autoimmune disease generation (Webster et al, 1998). Since ages, the basic principle of immunology has been the concept of clonal deletion of autoreactive immune cells and generation of a mature $\mathrm{T} \& \mathrm{~B}$-cell repertoire that could distinguish self from non self. The formation and survival of mature immune repertoire, always demands prolonged auto antigen exposure acknowledging the physiological importance of autoreactivity (Goldrath \& Bevan, 1999; Gu et al., 1991). Though structural resemblances exist between self and non self antigens the attack is directed against self antigens under stimulatory conditions like the presence of infections, cytokines etc (Silverstein \& Rose, 2000; Kanwar, 2005; Kanwar et al, 2009). Thus it is always fascinating to find answers for how the physiology of autoimmunity is turned to pathology and how the immune cells enforce their attack. This review focuses on introduction to immunity, pathology of autoimmune diseases and their treatments along with recent advancements. 


\section{Basics of immune system}

The immune system comprises of a complex array of immune cells tailored to defend the body against a variety of substances that are considered as foreign including pathogenic microbes and tumors while remaining nonreactive towards the self. Immune cells are originated from the haematopoietic stem cells and are classified as lymphoid and myeloid cells comprising B \& T-lymphocytes, Natural killer cells (NKs), dendritic cells and polymorphonuclear leukocytes, monocytes, mast cells, macrophages respectively (Delves, 2006). The immune cells constantly patrol the body and involve specific and non specific mechanisms in executing immune attack upon finding a foreign substance. The specificity rests particularly with $\mathrm{T}$ and B-cells as they display the receptors capable of recognising non self molecules from the self.

The specific attack is also complimented before by the strategic non specific immune responses generated by polymmorphonucelar cells, NKs, macrophages, co-stimulatory molecules like cytokines and serves as the initial site of attack upon finding the foreign entities. The abnormal levels of cytokines have a strong impact in the initiation and progression of autoimmune diseases. Also, therapeutic interventions with exogenous cytokines were found to be associated with the disease process, suggesting their key role in mediating the disease (Hooks et al., 1982; Trembleau et al., 1995; McKall-Faienza et al., 1998; Schattner, 1994; Kanwar et al, 1999; Kanwar et al, 2005; Kanwar et al, 2009). The complex network of immune cells is classified into subpopulations based on the expression of surface markers, functional characteristics, regions where they mature and activate. Likewise, Tcells include helper cells (Th) displaying $\mathrm{CD}^{+}$marker and involve in modulating the immune responses. Further they comprise subsets of Th1 cells that aid other T-cells and Th2 subtype mediates the antibody generation. Cytotoxic cells (Tc) with $\mathrm{CD}^{+}$marker are killer cells with lethal effect on intracellular pathogens, infected and tumor cells. Lastly, suppressor cells (Ts) down regulate and monitor the immune reactions. The naive T-cells undergo maturation in the thymus (hence the name T-cells) and are able to respond only to the processed antigens. Most of the nucleated cells of the mammalian system function as the antigen presenting cells (APCs) and dendrites are unique in this category expressing major histocompatibility complex proteins (MHC) and generating co stimulatory gestures for Tcell activation. APCs process the antigen and represent them in association with cell surface MHCs for T-cell recognition. These MHCs categorised as class I and Class II are crucial in the selection process of cytotoxic and helper cells respectively.

The T-cells bear an antigen recognition site on their surface called as T-cell receptor (TCR) and the initiation of T-cell mediated immunity requires the complex association of the antigen, MHC and the TCR. B-cells are specialised immune cells that act as APCs along with a prime function of antibody generation. The immature B-cells initially express a pre-B cell receptor (pre-BCR) on their surface and upon maturation they produce antibodies that act as antigen receptors towards the native antigen (Yang \& Santamaria, 2006; Austyn, 2000; Roitt et al., 1998; Janeway \& Travers, 1998). Both the T and B-cells express specific receptors for each antigen and this diversity is exhibited by the rearrangement of receptor gene sequences in the somatic cells rather than acquired through the inheritance (Gellert, 2002). In order to mount immune responses, the $\mathrm{T}$ and $\mathrm{B}$-cells are activated through corresponding receptors in the presence of co-stimulatory molecules (Crow, 2004; Kanwar et al, 2000; Kanwar et al, 2003; Kanwar et al, 2005). Another essential feature of both these cells is that, upon initial exposure to an antigen both these cells generate memory cells that expand clonally. These 
memory cells unleash an accelerated immune attack upon antigen re-exposure (Swain, 2003; Bishop et al., 2003).

\section{Tolerance}

Because of the expression of vast diversity of antigen recognition sites on $\mathrm{T}$ and B-cells, molecules that are considered as self also may find chances of binding with the immune cells. Hence, a diverse range of tolerance mechanisms have been developed that train the $T$ \& B-cells to differentiate self from nonself. This process is tightly controlled in the primary lymphoid organs and is continuous to inhibit the various modes of auto reactive lymphocyte generation and activation. The basic mechanisms dealt are clonal deletion, clonal anergy and inhibition of self reactive lymphocytes (Yoshida \& Gershwin, 1993; Rajewsky, 1996).

\subsection{T and B cell tolerance}

The tolerance mechanisms that develop in the primary lymphoid organs like thymus and bone marrow respectively for $\mathrm{T}$ and $\mathrm{B}$ cells constitute central tolerance. The naive T-cells originated from haematopoietic stem cells are devoid of CD4 and CD8 cell surface markers. Once migrated to the thymus, the TCR gene rearranges to develop double positive T-cells that display $\mathrm{CD}^{+}$and $\mathrm{CD}^{+}$. Then these cells are positively selected as $\mathrm{CD}^{+}$and $\mathrm{CD}^{+}$cells based on their interactions with the MHC class II and Class I respectively. The cells with TCR, that fail to bind or interact MHC with little affinity undergo death and are positively selected based on weaker interactions between TCR and MHC carrying self antigens. T-cells are killed if found to interact strongly with a self antigen displayed by MHC and thus selected negatively (Palmer, 2003; Starr, 2006; Bretscher \& Cohn, 1970; Kanwar et al, 2004; Kanwar, 2005). As a matter of enhanced protection from immune attack, the T-cells receiving stronger signals through TCR are deleted and this inactivation is much more sensitive compared to activation of T-cells that demand a stronger interaction between TCR and self antigen-MHC complex (Kappler, 1987; Pircher et al., 1991; Yagi \& Janeway, 1990). Similar tolerance mechanisms exist for B-cell repertoire, as they are negatively selected if the $\mathrm{BCR}$ is found to interact strongly with the self antigens. However, active investigation is recommended to determine the existence of positive selection for B-cells. Interestingly, successful T-lymphocyte tolerance cuts down the signals for few autoreactive B-cells and thus induces B-cell tolerance (Bretscher \& Cohn, 1970). During the course of their maturation, the pre B-cell receptor (BCR) cross links several avid auto-antigens. This event stimulates the rearrangement of light chain genes of the Ig's thus, driving the process of receptor editing where self antigens are replaced with non self ones (Ana et al., 2010). B-cells are deleted by apoptotic mechanism if found to interact strongly with self antigens (this happens mostly in bone marrow) and anergised if bound with little affinity (this happens mostly in periphery) (Monroe et al., 2003; Hodgkin \& Basten, 1995). T-cells have a potential role in the generation and progression of chemical and spontaneously induced autoimmune diseases and the same was also demonstrated successfully in the animal studies (Singer \& Theofilopoulos, 1990; Druet, 1989; Pettinelli \& McFarlin, 1989; Waldor et al., 1985). Few autoreactive T-cells may escape tolerance mechanisms and spread in the periphery but, they are naive and do not hold any threat unless APCs turn active. Potential problem persists 
incase of molecular mimicry (where pathogenic antigens resemble self antigens) as APCs turn active and trigger T-cell attack that is indiscriminate towards self and nonself. The same also holds true for B-cells (Damian, 1964; Oldstone, 1998). On the whole, generation of autoimmune diseases is based on the narrow margin that exists between tolerance and immunity executed by deletion and survival of self reactive lymphocytes. Too much deletion compromises the immunity and too little deletion follows subsequent autoimmunity. The following figure is an ideal representation of healthy and pathologic immunity and the differentiation between tolerance and autoimmunity.

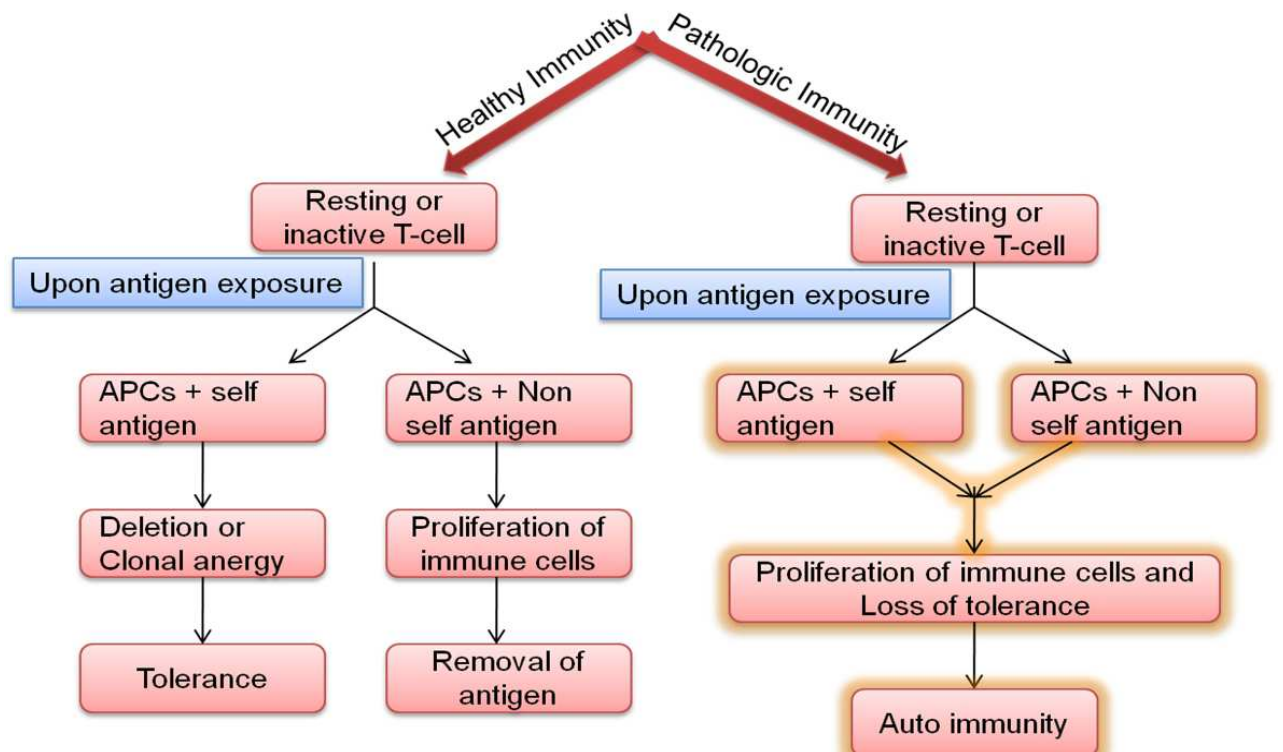

Fig. 1. Showing the comparison of healthy and pathologic immune system. A healthy T-cell upon exposure to self antigens undergo specific mechanisms of inactivation like deletion or clonal anergy constituting peripheral tolerance while an autoreactive T-cell is dysregulated with indiscriminate attack on self and non self antigens because of the lack of tolerance in autoimmunity.

\section{Autoimmune triggers}

\subsection{Genetics}

The enhanced knowledge of the mammalian immune system and the genetics lead to understanding the role of genes in autoimmune diseases. In the case of disease pathology, genetic variations are found to affect the MHC and several immunological pathways that in turn lead to the stimulation of autoimmunity. A number of studies have evidenced the potential role of genetics in the disease generation. Twin studies of multiple sclerosis (MS), rheumatoid arthritis (RA), Type- 1 diabetes and systemic lupus erythematosus (SLE) have reported a marked genetic predisposition of which the risk factor was found to be higher for monozygotic twins than the dizygotic twins. The risk of inheriting the systemic autoimmune 
diseases was also reported and this etiology could be due to the family history associated with the genetic vairaitons. In addition, a variety of MHC and non-MHC susceptible genes are identified in the genome wide studies of MS, SLE and RA while, few studies reported that many autoimmune diseases have a common genetic etiology operating (Glinda, 1999). Likewise, the association of intracellular tyrosine phosphatise, PTPN22 was shared in the pathologies of Type-1diabetes, RA and myasthenia gravis (Bottini, 2004; Begovich, 2004; Vandiedonck et al., 2006). In brief, genetics underscore a significant risk factor for the autoimmune etiology and presents a new area to explore.

\subsection{Auto antigens}

In the early stages of development some of the self antigens might escape recognition from the T-cell populations. This could happen because, they might not have been formed at the time of T-cell development or they might be separated from T-cell access due to remote anatomical existence (e.g. myelin basic protein) or due to the presence of membrane barriers or they might be inappropriately presented by the MHC proteins (Manoury, 1998). These cryptic antigens hinder the tolerance mechanisms and drive the autoimmune attack if they are encountered by the T-cells upon membrane barrier disruption for e.g. orchiditis upon vasectomy (Flickinger, 1994; Jarow et al., 1994) infections (Type 1 diabetes upon coxsackie B virus infection) or any other mechanism that exposes them (Yoon et al., 1979). A striking feature of auto antigens is that they are not specific to any tissue and form the integral components of all various cell types (Tan et al., 1987).

\subsection{Role of infections}

Infections have an interesting role to play in the induction of autoimmune diseases and there are several interesting mechanisms where infections mediate them. In the instances of microbial infections, immune cells cannot differentiate antigenic sequences from self proteins if structural similarities are found. This molecular mimicry unleashes the immune attack that is directed towards self and nonself leading to tissue destruction. For e.g. hepatitis B virus polymerase resembles myelin basic protein and generates auto antibodies that destroy myelin leading to multiple sclerosis (Fujinami \& Oldstone, 1989; Oldstone, 1998; Fujinami \& Oldstone, 1985). Infections are associated with interesting mechanisms that may enhance the severity of autoimmune diseases. Among these, epitope spreading is an instance where in an inflammatory burst, the avid APCs over process and presents the antigens to activate the large T-cell populations lowering the threshold to the disease onset. The other mechanism is termed as polyclonal activation where abundant B-cell populations are activated generating loads of antibodies along with immune complexes that pose serious threat to the tissues. The next mechanism involves the over activation and indiscriminate expansion of self reactive T-cells that are initially considered to be inefficient but can cause the disease in the presence of elevated levels of cytokines. Finally, microbes express super antigens on their surfaces that are unique in coupling T-cells with MHC complexes irrespective of their relativities (Barzilai et al., 2007a, 2007b). On the contrary when correlations were made between autoimmune diseases and infections, the incidences were found to be increased in the subjects who are at reduced risk of infections. The same holds true as autoimmune diseases have a rampant growth in western countries where the infectious incidences are lower compared to less developed nations (Bach, 2002; Patterson et al., 1996) substantiating the concept of hygiene hypothesis which states that the microbial exposure enhances the body's defence mechanisms ( Bjorksten B, 1994). 


\subsection{Role of cell adhesion molecules}

The propagation of autoimmune attack desperately needs the in and out migration of the immune cells, in particular T-cells, into the susceptible environment with potent inflammatory mediation. Cell adhesion molecules provide a suitable platform for this setting and are categorised as integrins, immunoglobulins and the selectins (Ziff, 1991). An autoimmune inflammatory setting leads to the enhanced expression of vascular endothelial proteins that constitute mucosal addressin cell adhesion molecule-1 (MAdCAM-1), intercellular adhesion molecule-1 (ICAM-1) and vascular cell adhesion molecule-1 (VCAM1). Correspondingly, the lymphocytes express the cell surface molecules P-selectin glycoprotein ligand-1 (PSGL-1), leukocyte function-associated antigen-1 (LFA-1) and very late antigen-4 (VLA-4) on their surface facilitating the adherence and entry of the immune traffic into the lesions and further enhancing the autoimmune spread (Dedrick et al., 2003; Kanwar et al., 1999).VLA-4 and LFA-1are specifically expressed by the human B cells (Alter et al, 2003) and therapeutic interventions with anti-adhesion molecule antibodies have witnessed successful termination of autoimmune disease severity in preclinical and clinical models (McMurray, 1996; Kanwar et al, 2000; Kanwar et al 2003; Kanwar, 2005; Kanwar et al 2009).

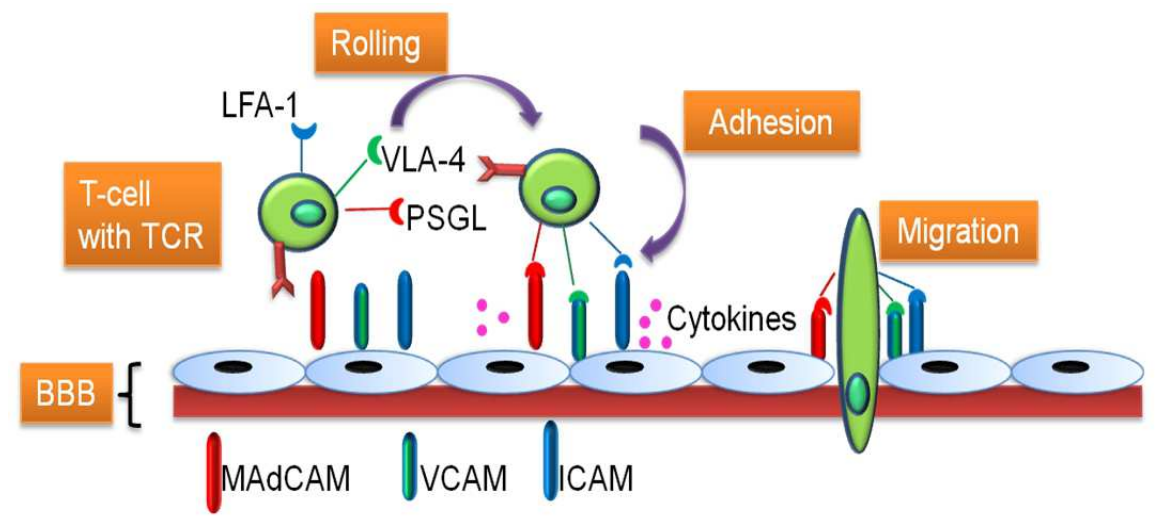

Fig. 2. Showing a typical T-cell exhibiting the phenomenon of rolling, adhesion and migration through the blood brain barrier (BBB) into the CNS. T-cell expresses PSGL-1, VLA-4 and LFA-1 on its cell surface and rolls over to adhere to the corresponding cell adhesion molecules, mucosal addressin cell adhesion molecule (MAdCAM), Vascular cell adhesion molecule (VCAM) and Intracellular cell adhesion molecule, (ICAM) respectively on the blood brain barrier capillary endothelial cells. These cell surface ligands are over expressed in an inflammatory condition facilitating the entry of T-cells into the BBB and thus initiating an autoimmune cascade.

\subsection{Long lived plasma cells}

The concept of long lived antibody secreting plasma cells were first demonstrated in a mouse model immunized with ovalbumin where in the plasma cells secreted antibodies against ovalbumin and the production was continuous independent of antigen exposure and memory cell assistance (Manz et al., 1997, 1998). The same was also observed in another mouse model infected with lymphocytic choriomeningitis virus (Slifka et al., 1998). The 
potential role of long lived plasma cells in the generation of autoimmune diseases was studied in NZB/W mice that served as a model for systemic lupus erythematosis (Hoyer et al, 2004). The differentiation of B-cells leading to the generation of memory cells and antibody secreting plasma cells is guided both by the antigenic and non antigenic stimuli (Tarlinton et al., 2008; Radbruch et al., 2006). However not all antibody secreting plasma cells turn long lived as it entirely depends on the antibody titre maintenance for the generation of secondary immune responses (Manz et al., 2005).

Long lived plasma cells mainly originate from the germinal centre regions and require a close reciprocation of the T and B-cells. But, once generated these cells act independently. In one of the autoimmune pathologies, it was found that self reactive B-cells are not excluded from the germinal centre region allowing the production of long lived plasma cells that were autoreactive (Cappione et al., 2005). This concept of long lived plasma cells is novel and serves as attractive targets for treating autoimmune diseases.

\subsection{Auto antibodies}

The role of auto antibodies in the pathogenesis of autoimmune diseases is often elusive but considering few autoimmune diseases like myasthenia gravis, the antibodies are specific to cell surface receptors. The basic principle for the autoantibody directed cytotoxicity is the identification of cell surface antigen followed by cell death mechanisms either through complement activated system, antibody dependent cell mediated cytotoxicity (ADCC) or by the macrophage uptake mechanism (Ohishi et al., 1995; Frisoni et al., 2005). Complement activated system is constituted by a collection of specific group of plasma proteins and are considered to be more prevailing in autoimmune diseases. The class of autoimmune haemolytic anaemia, lupus syndrome typically fall under the complement system generated autoimmune diseases (Fang et al., 2009). In the case of classical ADCC, NKs play a prime role in mediating the cell death, after the binding of antibody with the target antigen. NK's binds the Fc portions of these antibodies and induce cell death by free radical generation. Autoimmune thyroid disease is a fine example of ADCC mediated autoimmune disease (Rodien et al., 1996). Finally, macrophages execute the uptake and cell lysis processes once they find the appropriate antibody-antigen interaction (Gehrs \& Friedberg, 2002). In general, the auto antibodies are directed to intracellular antigens and this understanding unveils fascinating questions of how they interact with intracellular antigens. The possible explanation could be because of the cross reaction of surface antigens with the intracellular antigens (Frisoni et al., 2005) and the exposure of intracellular components after lysis due to an impaired macrophage phagocytosis (Hansen et al., 2002). The potential significance of auto antibodies in autoimmune diseases were also demonstrated in the foetus as few of the immunoglobulin's (IgG) can cross the placenta and target the cell surface creating a havoc of tissue destruction (Clancy et al., 2004a, 2004b). Also, the apoptotic cells were found to be potent enough to generate autoantibodies if accompanied by other moieties like dendritic cells or Freunds incomplete adjuvant. These dying cells tend to activate Toll like receptors and NF-kB pathway that are associated with inflammation which in turn is linked to generation of autoantibodies (Bondanza et al., 2004), in conclusion it has to keep in mind that, auto antibodies are not always associated with the disease and few of them are valuable diagnostic aids implicated in a clinical setting.

\subsection{Stress and autoimmune diseases}

Stress of both versions physical and physiological is found to be associated with the disease generation. This was also supported from the several past studies that emotional stress was 
highly proportionate for predicting the disease onset. These two are related because, stress presumably shoots the neuroendochrine triggers that are predicted to alter the immune function or the cytokine levels ending up with the disease generation (Herrmann et al., 2000; Stojanovich \& Marisavljevich, 2008). Also, stress induces the expression of heat shock proteins that are highly immunogenic with a potential of triggering autoimmune diseases (Kanwar et al., 2001). Therefore, therapeutic interventions for these diseases should consider management of emotions and stress.

\subsection{Pregnancy and autoimmune diseases}

In order to escape the immune attack neither the sperms nor the developing trophoblast bear the MHC proteins of either class. This peculiar feature allows the escape and survival of the sperm from the immune attack to fertilize the ovum (Johnson, 1993). Soon after fertilisation, many protective measures are adopted to protect the developing foetus and likewise it bears the human leucocyte antigen (HLA-G) marker which if otherwise would have been killed by the natural killer cells (VanVoorhis \& Stovall, 1997). Also regulatory proteins from the foetus avoid the activation of complement system and its subsequent attack (Holmes \& Simpson, 1992). Interesting immunological features are noticed in a pregnant woman, as changes are seen in the immune reactions that shift from Th1 to Th2 type due to the release of cytokines like TGF-beta (Raghupathy, 1997; Lim et al., 1998). This modification has a striking implication in that many of the pregnant woman experience remission of autoimmune diseases like rheumatoid arthritis (RA) and multiple sclerosis that are Th1 mediated (Allebeck et al., 1984; Cutolo \& Accardo, 1991). However the risk of systemic lupus erythematosis (SLE) in pregnant woman is much higher compared to non pregnant woman and this also has drastic effects on the survival of the foetus (Khamashta et al., 1997; Cooper et al., 2002; Fraga et al., 1974).

\section{9 $\mathrm{T}$ and B-cell traffic in the CNS}

The migration of T-cells into the CNS adopt the same principles as they enter the peripheral tissues namely, activated T-cells migrate the tissues from the blood where as inactive ones remains in the lymph vessels (Mackay et al., 1990). To demonstrate the migration of T-cells into the CNS, Hickey et al administered labelled T-cells intravenously and observed the appearance of T-cells in the brain parenchyma soon after $3 \mathrm{hrs}$ (Hickey et al., 1991). Also, Tcells in very minute levels were detected in the rat and human brains suggesting the fact that they continuously monitor the CNS (Pender, 1995). Similarly B-cells cross the BBB, perhaps more rapidly than the T-cells and differentiate into the plasma cells in response to an antigen as they do in the periphery (Knopf et al., 1998; Anthony et al., 2003; Kanwar, 2005). The following figure 3 represents the autoreactive T-cell entry and further consequences that lead to the generation of autoimmunity.

\subsection{Co-stimulatory molecules}

The phenomenon of T-cell activation and the generation of autoimmunity also depend on the involvement of several co-stimulatory molecules like B7-1, B7-2, CD28, inducible co stimulator (ICOS), OX 40 and CD40 ligand that are associated with T-cell activation. Other molecules like cytotoxic T lymphocyte antigen 4 (CTLA-4) and programmed death 1 (PD-1) regulate negative co-stimulation. Hence, effective therapeutics targeting these molecules will have a significant impact in the autoimmune disease control (Racke \& Stuart, 2002; Kanwar et al 2004). 


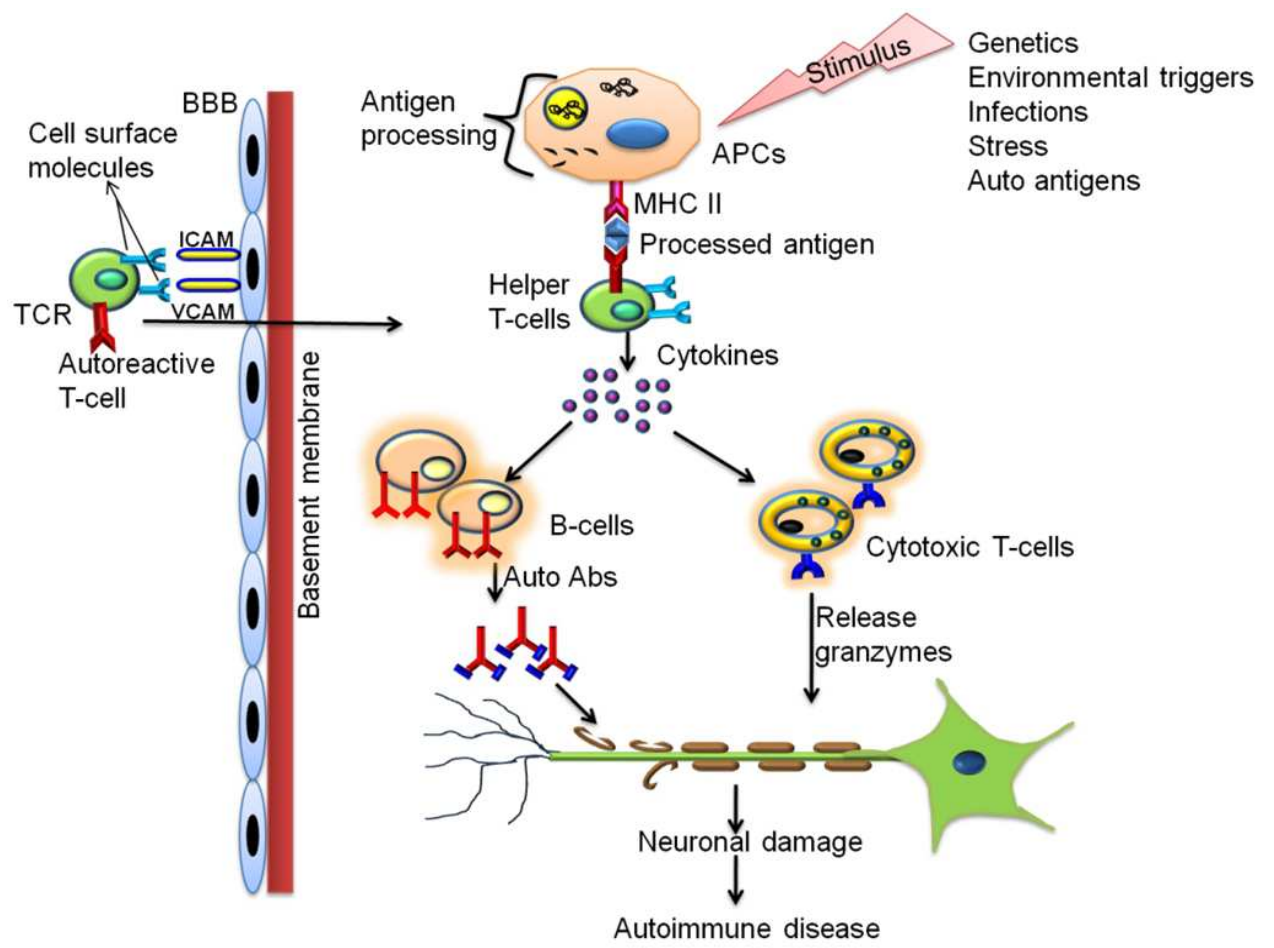

Fig. 3. Schematic representation of autoimmune attack in the CNS APCs-Antigen presenting cells; BBB-Blood brain barrier; ICAM- intercellular cell adhesion molecule; MHC-Major histocompatibility complex; TCR-T-cell receptor; VCAM- Vascular intercellular cell adhesion molecule.

The auto reactive T-cells gain entry into the CNS by the pairing of cell surface molecules leukocyte function-associated antigen-1 (LFA-1) and very late antigen-4(VLA-4) with the cell adhesion molecules, intercellular cell adhesion molecule (ICAM) and vascular cell adhesion molecule (VCAM) expressed on the brain capillary endothelium. Once after entry the helper T-cells (Th) bind with the processed peptide fragments presented along with MHC II by the antigen presenting cells (APCs).The threshold for triggering immune attack is lowered in autoimmune diseases and is stimulated by a variety of factors. The Th cells secrete a variety of cytokines that further activate the cytotoxic T-cells (Tc) and the antibody secreting B-cells. Tc cells, when activated mediate the cytotoxicity by releasing the granzymes while the Bcells differentiate into plasma cells that produce auto antibodies against a variety of targets like the myelin, nicotinic acetylcholine receptors (NAchRs), voltage gated calcium channels (VGCC), voltage gated potassium channels (VGKC), glycolipids etc mediating the corresponding neurological autoimmune disorder.

\subsection{Autoimmunity and survivin}

In an effort to address issues involved with the treatment of neurodegenerative and autoimmune diseases, the two following strategies can be employed: a neuroprotection 
strategy and a neuroproliferative strategy. Findings suggest that $\mathrm{Bcl} 2$ and IAP inducers are able to inhibit apoptosis for the purpose of neuroprotection in preclinical models (Kanwar, 2010a-d, Baratchi, $2010 \mathrm{a \& b}$ ). Our understanding of neurodegenerative diseases has improved over the past two decades. Whereas these disorders are initiated due to a range of insults such as reactive oxygen species or misfolded proteins, all of these pathologies end with a common consequence, which is the degeneration and deterioration of neuronal cells (Kanwar et al, 2010a). Despite all of the efforts to understand and treat neurodegenerative diseases, their successful treatment has still not been achieved. A proper treatment should not only protect neural cells but should also increase their proliferation and differentiation so as to provide a promising future for an aging population and families with a history of degenerative disorders, including multiple sclerosis, Parkinson's disease and stroke. The brain's environment is the most protected part of our body and neurons are a unique cell type (Baratchi, 2011a\&b). Despite playing an important role in the analysis and transfer of information to the entire body, the lack of neural self-proliferation and repair highlights the importance of their protection and proliferation. To be able to protect these cells from death and to facilitate their proliferation involves mechanisms that still need to be identified. Experimental findings achieved over the past few years have suggested that inhibitors of apoptosis (IAP), which serve a natural role in balancing cell death, might be candidate proteins with a unique potential for drug discovery (Kanwar et al, 2010). Recently we reviewed the exceptional capabilities of survivin (a unique member of IAPs) in both cell cycle and cell death pathways and its unique characteristics related to neuronal cell survival and proliferation (Baratchi, 2010a\&b).

Given that this is the first report of a protective effect of SurR9-C84A following an oxidative stress injury, further work should be done to study the effects of SurR9-C84A on in vivo models of degenerative diseases. In summary, we reported for the first time, a recombinant, cell-permeable form of the survivin mutant protein (SurR9-C84A) efficiently enters neuronal cells, protects differentiated SK-N-SH cells from the activation of apoptosis induced by $\mathrm{H}_{2} \mathrm{O}_{2}$, decreases the expression of cell cycle markers, and increases antioxidant activity. Emerging nano-delivery systems could be used to bypass the blood brain barrier, facilitating drug delivery to the damaged brain. Survivin is a member of the IAP family, which has been shown to have a role in early brain development and serves a bifunctional role during mitosis and inhibition of apoptosis (Baratchi et al., 2010a; Kanwar et al., 2010). Different forms of survivin mutants (such as C84A, $\Delta 106$ and T34A) have been used for the purpose of targeting survivin overexpression in cancer cells (Cheung, 2010a\&b; Kanwar et al, 2010b; (Baratchi, 2010a\&b). Among the various survivin mutants, the baculovirus IAP repeat motif (C84A) was initially produced and has since been shown to have proapoptotic effects on human cancer cells. Furthermore, we previously found that SurR9-C84A has protective effects against retinoic acid induced cell toxicity (Baratchi et al., 2011b). We used the SK-N$\mathrm{SH}$ cell line as a culture model of retinoic acid-induced neuronal differentiation (Baratchi, $2010 a \& b)$. We showed for the first time, the neuroprotective effect of SurR9-C84A against cytotoxic elements existing in activated T-cell supernatants such as GrB. Because GrB is a powerful pro-apoptotic member of granzymes family and is a very important mediator of damage in progressive MS and other neuro-inflammatory disorders we examined the importance of GrB released from the activated T-cells in an in-vitro system and compared the protective effect of SurR9-C84A with GrB inhibitor (Baratchi, 2011a\&b). SurR9-C84A can be applied in neuroprotective strategies to protect differentiated neural cells from cell cycle re-entry and apoptosis. Additionally, one important advantage of this mutant over the wild 
type survivin is that it does not form tumour due to its pro-apoptotic effect in cancer cells. Because the over-expression of survivin has been reported in stimulated T-cells derived from patients with active MS, the neuroprotective ability of SurR9-C84A has the potential to be employed for future neurodegenerative therapies, and may also be further evaluated for targeting stimulated T-cells for the treatment of neurodegenerative diseases such as MS and other brain injuries (Baratchi, 2010a\&b).

\section{Classification of autoimmune diseases}

Autoimmune diseases are characterised by the abnormal activation of the immune responses against our own tissues evidenced by the inability of the immune cells to differentiate self from non self antigens. Hence, mistakenly immune attack is directed towards our own body parts. They are categorised as systemic, involving multi target organ damage (e.g. systemic lupus erythematosis) or they can be localised involving damage to a single organ. (e.g. Type 1 diabetes) (Mackay \& Rosen, 2001).

A list of autoimmune neurological diseases are included and described as follows (Dalakas, 2006).

\subsection{Multiple sclerosis (MS)}

MS is a localised neurological autoimmune disease and is marked by the characteristic inflammation and degradation of the protective nerve lining, the myelin (Lucchinetti et al., 2000; Lassmann, 2000). More than 1 million people are affected by MS with a characteristic presentation of weakness, abnormal senses, ataxia, poor balance, fatigue, vision loss and impaired cognition (Fugger et al., 2009; Kanwar et al 2004; Kanwar, 2005). Based on the histopathology multicentred inflammatory lesions were observed in the patient's brain and the spinal cord (Frohman et al, 2006). Multiple aetiological factors are involved in the preponderance of the disease and are often found to be triggered by a viral infection (Lucchinetti et al., 2000). This initiation by an infection is by the process of molecular mimicry as discussed earlier. It is rather fascinating to study the generation of inflammatory lesions and the entry mechanisms of immune cells in MS. A specific population of activated T-cells that are selective towards myelin crosses the blood brain barrier under the strong influence of chemokines while the resting T-cells are inaccessible towards the BBB due to the unfeasible environment (Charo \& Ransohoff, 2006).

The cell surface molecules (integrins, selectins and cadherins) of the T-cells bind with the adhesion molecules expressed on the brain endothelial cells and finally escape into the CNS. Following their entry, the T-cells then direct the immune attack towards myelin antigen presented on their surface by the APCs (Greter et al., 2005). Along with macrophages, dendritic cells, glial cells and astrocytes present the MHC class II expression in the CSF and thus attract the T-cell traffic (Heppner et al., 2005; Greter et al., 2005). Under the influence of activated T-cells the immune attack is boosted up towards the myelin sheath and is executed by recruiting the T-cells and antibody secreting B-cells from the periphery driving the myelin assault leading to demyelination (Cepok et al., 2005; Steinman, 2002). The severity and progression of the demyelination process is influenced significantly by the B-cells as evidenced by the infiltration of macrophages and the deposition of immunoglobulins (Lucchinetti et al., 2000). The same was also supported by the observations made on clonal expansion and the presence of IgG complexes of B-cell populations in the brain and cerebrospinal fluid lesions (Qin et al., 1998; Baranzini et al., 1999; Colombo et al., 2000). The 
whole process of immune attack and tissue damage is also encouraged by the active macrophages and glial cells (Brosnan \& Raine,1996; Heppner et al., 2005). Interesting results were obtained from the animal model of MS, experimental autoimmune encephalomyelitis where it was found that, the pro-inflammatory $\mathrm{T}$ cells of Th1-type were found to be responsible for the disease exacerbations (Wekerle et al., 1986; Gold et al., 2006). There are four subtypes of MS and categorised as relapsing remitting (RR) with majority of the patients displaying recovery symptoms after disability. People who experience RR often complain a second variety of MS termed as secondary-progressive MS where the disability doesn't subside between the cycles of relapses and recoveries. The third form is the primary progressive stage where there is only progression and no remission. The last form of MS is rather rare and termed as Progressive-relapsing MS (PRMS) characterised by the severe attacks and symptoms during the remission period (Mayoclinic, 2008). More than 1 million people are affected by MS with a characteristic presentation of weakness, abnormal senses, ataxia, poor balance, fatigue, vision loss and impaired cognition. Significant contributions are being made for the disease diagnostics and management with the introduction of potential biomarkers. There are findings of glial fibrillary acidic protein (GFAP) and neurofilament light protein (NFL) (the cytoskeletal proteins of astrocytes and axons respectively) release into the CSF during the disease progression (Axelsson et al., 2010).

As per clinical data, the plasma levels of osteopontin was increased well before the induction of lesions with gadolinium $(\mathrm{Gd})$ and similar profiles were observed with 7KC and 15 oxy sterol derivatives of cholesterol in MS patients. Added to this, enhanced antibody binding was reported towards these entities suggesting their potentials as biomarkers (Vogt et al., 2003; Whitaker, 1987). Also in a longitudinal cross sectional study of MS patients, it was found that levels of pentosidine, a well characterised biomarker for advanced glycation end products (AGE) were significantly elevated compared to the healthy controls. It was also observed that patients on treatment showed pentosidine down regulation compared to untreated patients. Thus, this study considers the AGE inhibitors as novel therapeutic interventions against MS. ( Sternberg et al., 2011) The recent reports on the associated tissue damage in MS patients found that it is not only limited to axons but also included significant retinal damage (Green et al., 2010).

The current therapeutic strategies for MS include the treatment for disease progression and the symptoms. Interferon's of type I (IFN-1) specifically marked as IFNb1a, IFNb1b and glatiramer acetate are considered as the first line drugs against RR form of MS but have a limited effectiveness. The mechanism of these drugs is that they down regulate the proliferation of T-cells, reduced antigen presentation, T-cell migration (interferon's in particular) and shift the immune response to Th2 type (Clerico et al., 2007; Arnon \& Aharoni, 2004). Natalizumab, a humanized monoclonal antibody (mab) is found effective against MS as it inhibits the entry of T-cells into the CNS by acting against the cell surface molecule a-integrins and showed significant reduction in the relapse rate compared to the above treatment strategies (Polman et al., 2006). However, limitation exists on its indiscriminate use as it poses a serious risk of brain infection, progressive multifocal leukoencephalopathy (PML) that even causes death (Clifford et al., 2010). Corticosteroids like prednisone, prednisolone, methyl prednisolone and dexamethasone are also used against the RR and rarely against secondary progressive multiple sclerosis as they act by suppressing the immune system. They are strictly contraindicated for long term use as they are associated with a number of side effects (Merck,). Chemotherapeutics with a potential of suppressing the immune system like mitoxantrone inducing the apoptosis of lymphocytes 
and cyclophosphamide acting against both the T \& B-cell activities, were also tried against RR and secondary progressive MS (Chan et al., 2005; Fauci et al., 1971; Multiple Sclerosis Treatments). The drugs in development for MS are Fingolimod and BG00012 that are in phase II clinical trials. Fingolimod acts by complexing the lymphocytes in the lymph nodes preventing their entry into the CNS and BG00012 is an oral formulation of Fumarate and presumed to act by neuroprotective and anti-inflammatory mechanisms inhibiting the oxidative stress (Lutterotti \& Berger, 2010). Drugs in phase III clinical trials for RR form of MS are Laquinimod that acts by shifting the T-cell response to Th2 type and Teriflunomide acts by interrupting pyrimidine synthesis inhibiting the dihydro-orotate dehydrogenase and stops the expansion of $\mathrm{T}$ and $\mathrm{B}$ cells. Cladribine is efficient against both the resting and dividing T-cells and acts against the adenosine deaminase enzyme (Yang et al., 2004; Warnke et al., 2009). Monoclonal antibodies are also under evaluation and CAMPATH is tried against the CD52 expression on leukocytes. This activity depleted a majority of the lymphocytes, monocytes and dendritic cells in MS patients (Osborne, 2009; Hauser et al., 2008). A similar effect was observed with Rituximab that acts against the CD20 expression.

\subsection{Myasthenia Gravis (MG)}

In the case of myasthenia gravis the prototypic B cells produce the auto antibodies that are directed against the nicotinic acetylcholine receptor (AchR) in the neuromuscular junction (NMJ) (Drachman, 1994; Ragheb \& Lisak, 1998). These antibodies from the peripherally activated B cells infiltrate the end-plate region of NMJ, and down regulate the functionally active Ach receptors either by cross linking the receptor followed by internalization or by initiating the complement-mediated immune destruction or they may make the binding site unavailable for activity (Bufler et al., 1996). Following this, the signal transmission and communication is significantly affected between the neurons and the muscles in NMJ region due to the immune attack.

Based on the symptom severity there are three subtypes of MG, Pure ocular MG characterised by weakness and fatigue of extra ocular muscles, resulting in ptosis and diplopia. Generalized MG, with extensive skeletal muscle weakness and finally myasthenia crisis, with disturbances in swallowing and respiratory failure (Hohlfeld et al., 2003). The exact role of antibodies in the pathogenesis of myasthenia gravis was confirmed from the results that, administration of myasthenic IgG antibodies generated the symptoms while the symptoms were ameliorated upon their removal (Drachman, 1994; Vincent et al., 2000). In a patient subgroup with myasthenia gravis, another variety of autoimmunity was reported with the detection of auto antibodies directed towards the muscle specific kinase. These patients were considered as seronegative to MG. (Vincent et al., 2003). The treatment modalities for MG include the acetylcholinesterase (AchE) inhibitors as the mainstay of treatment as they improve the bioavailability of Ach in the NMJ and the immune modulating agents. The AchE inhibitors of clinical significance are the pyridostigmine and neostigmine. They act by binding with AchE enzyme because of structural resemblance to Ach and slowly get hydrolysed compared to it. This improves the availability and subsequent binding of Ach to the available AchR in the NMJ. The common adverse effects associated are disturbances of GIT, respiratory system, cardiovascular system and glandular secretions (Kumar \& Kaminski, 2011).

\subsubsection{Agents acting on immune system}

Glucocorticosteroids with a potential of strong anti-inflammatory and immunosuppressive activity are tried with a successful outcome. The orally administered glucocorticoids 
(prednisone in common) show a delayed onset of action and take even months to exhibit maximum therapeutic benefit (Hohlfeld et al., 2003). However, intravenous administration is recommended for the management of exacerbations (Arsura et al., 1985). Long-term treatment is not recommended due to the severe side effects featuring crushing's syndrome, obesity, precipitation of diabetes, gastrointestinal ulcers, opportunistic infections and hypertension etc. In the class of immune suppressive drugs, Azathioprine is the prominent and well tolerated drug tried against MG patients. This is a purine analogue and displays significant decrement in the levels of both T \& B-cells thus monitoring the immune attack. Added to its mechanism it also exhibits anti-inflammatory actions by inhibiting promonocyte cell proliferation. It is generally given in combination to lower the dose of glucocorticoids but can also be prescribed alone for long term therapy (Mertens et al., 1981; Gold et al., 2003). Cyclosporine-A acts by binding to an intracellular protein, cyclophilin and forms a cyclosporine-cyclophilin complex. This complex exhibits immunosuppressive activity by inhibiting the phosphatase, calcineurin and prevents the cytokine formation. The clinical significance of this drug was that, it was the first drug tried in a double-blind and placebo-controlled trial MG patient population (Tindall et al., 1987). Patients with refractory MG show better responses towards cyclophosphamide, methotrexate and mycophenolate mofetil (Schneider-Gold et al., 2006). The recent advancements included are the administration of intravenous IgG that has a potential blocking activity against auto antibodies. This treatment is recommended when all the treatment modalities have failed. (Zinman et al., 2007) Advancements are made in the therapeutics of MG with the introduction of SHG2210, a novel entity with a potential to fuse with the a-subunit of the auto antibodies that are directed against AchR. This SHG2210 -autoantibody fusion complex is later cleared by the transferrin receptor mediated cellular uptake (Keefe et al., 2010).

On the whole due to the advancements made in the diagnosis and treatment, MG stands as a rear but treatable autoimmune disease.

\subsection{Guillainbarre syndrome (GBS)}

GBS is classified as an acute auto immune disease of demyelinating type mostly affecting the peripheral nervous system. Depending upon the target affected by the immune attack it is categorised to 4 subtypes. The first of its kind is the acute inflammatory demyelinating polyneuropathy (AIDP) where the immune attack is directed towards the myelin or schwann cell surface membrane. The next subtype is the acute motor axonal neuropathy (AMAN) targeting the axonal membrane in motor fibres where as both the motor and sensory nerve fibres are targeted in acute motor sensory axonal neuropathy (AMSAN). In the last subtype, distal nerve terminals and nodal regions of the ocular motor nerve are affected and termed as Miller Fisher syndrome (MFS) (Willison et al., 2002; Kuwabara, 2004). GBS is often triggered by an infection of bacterial or viral origin with auto antibodies directed against gangliosides particularly in AMAN where infections with campylobacter jejuni produced auto antibodies against GM1, GM1b, GD1 or Ga1NAc-GD1a gangliosides (Ogawara et al., 2000). There were also detectable levels of IgG and complement deposition in the nerves (Hafer-Macko et al., 1996). The distinct involvement of $\mathrm{T}$ and B-cells are identified in few subtypes, with the activated complement system playing a prime role in mediating demyelination and impaired conduction but still understanding the pathology of GBS remains rather elusive (Kieseier et al., 2004). The treatment for GBS is often confined to the immunomodulatory therapy where plasmapheresis and intravenous administration of immunoglobulin's IVIg are given the priority (Dalakas, 1999; Hadden et al., 1998). 
Plasmapheresis is the plasma exchange where the immunoglobulins and antibodies are removed from the serum with a subsequent separation of the blood cells. Then these blood cells are isolated and added to the fresh plasma or saline to administer back into the patient. IVIg operates through multiple mechanisms that include the inhibition of antibody production, complement binding, macrophage receptor blockade and the abnormal antibody neutralisation. Both these strategies were found to have equal efficiencies in reducing the disease progression (Heather Rachel Davids).. Future therapies for GBS are directed towards the complement inhibitors. (Walgaard et al., 2011)

\subsection{Neuromyelitis optica (NMO)}

The pathology of this neurological autoimmune disorder is clear with the detection of antibodies against the aquaporin -4 water channels of the endothelial cells in the CNS (Lennon et al., 2005). In the autopsy studies, deposition of Immunoglobulins particularly of the IgM subtype were detected in the lesions with activated complimentary system leading to vascular damage. The predominant immune attack directed in this disorder is of the humoral type with majority of the attack directed towards the optic nerve and the spinal cord (Lucchinetti et al., 2002; Wingerchuk et al., 2004; Bergamaschi, 2007). Immunosuppressive therapeutics like mycophenolate mofetil, mitoxantrone and rituximab are far beneficial rather than immunomodulating agents like interferons in NMO(Bergamaschi, 2007).Eculizumab, is a new molecule under Phase I/II clinical trials and the proposed mechanism for this entity is that it inhibits the complement activation and subsequent destruction (. clinicaltrials.gov.).

\subsection{Stiff-Man syndrome (SMS)}

Stiff man or Stiff-person syndrome is also a predominant antibody directed autoimmune disease with majority of the auto antibodies directed towards the enzyme, glutamic acid decarboxylase (GAD) that is essential for the synthesis of gamma-amino butyric acid, a principal inhibitory neurotransmitter in the brain. Also, detectable levels of Immunoglobulin belonging to the subtype IgG were found in the CSF confirming the infiltration of B-cells (Dalakas et al., 2001; Ishii, 2010). The recent epidemiological studies report the existence of anti-gephyrin, anti-amphiphysin and anti-gamma-aminobutyric acid A receptor-associated protein (GABARAP) antibodies in the disease pathology. The patients experiencing this disease complain symptoms of muscular rigidity in the legs and trunk region often associated with muscle spasms (Dalakas et al., 2000). The medication for stiff man syndrome initially should begin with the skeletal muscle relaxants benzodiazepine or baclofen. Intrathecal administration of baclofen was even considered in a selected patient group. However great care has to be taken in performing this procedure as it is involved with puncturing the meninges (Duddy \& Baker, 2009). Other treatment options considered are plasmapheresis and administration of Intravenous immunoglobulins like Gamimune, Gammagard, Sandoglobulin (Dalakas, 2009; Hayashi et al., 1999).

\subsection{Paraneoplastic neurological syndromes (PNS)}

The pathology associated with this autoimmune disease is quite peculiar. Antigens that are confined to the nervous system are capable of mediating an immune attack if the same antigens are expressed in the case of pathological conditions such as the breast or ovarian cancers. The immune cells that are activated against these antigens also direct their attack 
indiscriminately towards the antigens of the CNS that were once considered as self. A diverse range of self-antigens are identified in this setting and within this diversity, multiple epitopes are recognized within each antigen encountered. Thus, stimulated by the cancers, immune drive is targeted against the CNS evidenced by the detection of serum antibodies. The most common serum antibody detected is the anti-Hu antibody in patients coexisting with sensory neuropathy, encephalomyelitis or cerebellar ataxia (Dalmau et al., 1992; Graus et al., 2001; Darnell \& Posner, 2003; Maverakis et al., 2011). Other such auto antibodies detected are antiYo antibodies in cerebellar degeneration (Peterson et al., 1992) anti-Ma1 and anti-Ma2 antibodies in limbic encephalitis in patients with testicular cancer (Rosenfeld et al, 2001) and antibodies in Lambert-Eaton myasthenic syndrome in small cell lung cancer patients (Carpentier \& Delattre, 2001). In the paraneoplastic autoimmune CNS disorders, immune cells penetrate the blood-brain barrier and the antibody mediated destruction serves as the dominant mode of immune attack as evidenced by the localised synthesis of antibodies by the B cells (Darnell \& Posner, 2003 \& Pranzatelli et al., 2004). However, defining the precise mechanisms of cellular and humoral pathways in the pathophysiology is still unclear and the immune system adapts the elusive mode to identify the intracellular antigens.

The treatment for this disorder should be aimed at treating the underlying tumor with standard anticancer therapeutic regimen while the immune mediated disorder is treated by plasmapheresis or administration of immune suppressive drugs like Cyclosporine and glucocorticoids. Cyclosporine acts against both the cell and humoral mediated immune reactions and glucocorticoids are the potent anti-inflammatory and immune suppressive agents as discussed. Immune reaction suppression is even achieved by the administration of IVIg and Antithymocyte globulin is recommended in this case. It is a polyclonal IgG antibody particularly effective against T-lymphocytes and reduces the count to $85-90 \%$ (Buchwald et al., 2005; Koski \& Patterson, 2006).

\subsection{Lambert-Eaton Myasthenic Syndrome (LEMS)}

Lambert-Eaton syndrome is a muscular disorder characterised by the autoantibody generation against the voltage gated calcium channels in the presynaptic nerve terminals. The communication is drastically affected between the nerves and muscles due to the inability of the nerve cells to release Ach required for muscular contraction. Hence, the symptoms of muscular rigidity and weakness are experienced in the patient population. The difference noticed between MG and LEMS is that in the latter form of the disease, with repeated contractions the muscle gets stronger for a shorter span of time instead of turning weaker (Lambert-Eaton syndrome, 2000). The primary treatment for LEMS aims to enhance the levels of Ach either by increasing its release or by inhibiting its metabolism thus making it available at the NMJ. The agents that are considered effective in this regard are Pyridostigmine bromide, 3,4-Diaminopyridine (DAP) and guanidine $\mathrm{HCl}$. Pyridostigmine is an AchE inhibitor and shows symptomatic relief, while DAP and guanidine HCL acts by enhancing the release of Ach with noticeable improvement in the muscular strength. Patients who are refractory to the above treatment are prescribed with the immunosuppressive drugs as mentioned earlier (McEvoy et al., 1989; Sanders, 1995).

\subsection{Neuromyotonia (NM)}

Neuromyotonia, is a rare autoimmune disorder with antibodies directed against the voltage gated $\mathrm{K}^{+}$channels of the Shaker-type (Kv1). Based on the symptoms observed the disease is 
categorised as acquired neuromyotonia (NMT) with peripheral nerve hyperexcitability, fasciculations and muscle stiffness. Morvan's syndrome is associated with the symptoms of NMT along with encephalopathy and sleep disorders. The last subtype is the limbic encephalitis characterised by the CNS involvement with encephalopathic seizures, hyponatremia and abnormal electroencephalographic abnormalities. The antibodies noticed in this immune disorder were pathogenic and were confirmed by the observations of electrophysiological changes in mice, upon administration of IgG derived from patients (Kleopas et al., 2006; Buckley \& Vincent, 2005; Merchut, 2010). Recently, a novel pathology was attributed to limbic encephalitis in which auto antibodies were identified against leucine-rich glioma-inactivated 1 (LGI1) protein. Previously, these auto antibodies were assumed to be acting against $\mathrm{K}^{+}$channels and hence, this disorder is now termed as limbic encephalitis associated with LGI1 antibodies (Lai et al., 2010).

Most of the patients with these disorders fairly respond when treated with immunosuppressive drugs like glucocorticosteroids. Also other recommendations include plasmapheresis and IVIg (Merchut, 2010).

\subsection{Polyneuropathies (PN)}

Polyneuropathies are divided into 3 subtypes as chronic inflammatory demyelinating polyneuropathy (CIDP), multifocal motor neuropathy (MMN) and IgM anti-myelinassociated glycoprotein (MAG) demyelinating neuropathy (Kornberg \& Pestronk, 2003; Czaplinski \& Steck, 2004; Kieseier et al., 2004). Both the T and B-cell mediated immune havoc is noticed in CIDP with the majority of antibodies directed towards the glycolipids GM1 (Yan et al., 2000). Similar type of antibody production is identified against GM1 in half of the patient population in MMN but the pathogenecity of these antibodies are left unidentified (Nobile-Orazio, 2001). On the contrary, the IgM antibodies generated against the myelin associated glycoprotein in anti-MAG neuropathies are identified as pathogenic with a successful transfer of the disease to the animals. The normal cellular interactions were also found to be disturbed by these anti-MAG antibodies by the complement activation towards the myelin lamellae (Latov, 1994; Dalakas \& Quarles, 1996; Quarles \& Weiss, 1999). The treatment options considered are mainly immunosuppressive in nature and administration of glucocorticosteroids, plasmapheresis and IVIg are in use (Shy, 2007). Figure 4 summarises the pathologies of all the neurological autoimmune diseases.

\section{What's in the pipeline?}

The role of B-cells in the autoimmune disorders is inevitable and considering this concrete paradigm researchers have now focussed targeting them with the mainstay of B-cell depletion. The targets identified were the B-lymphocyte stimulator (BLyS) protein and the CD20 expression on B-cells. Belimumab, is the humanised anti-BLyS monoclonal antibody and showed effective inhibition of invitro B-cell proliferation. (Baker et al, 2003) Also, phase I clinical trials of belimumab in SLE was well tolerated and further results are yet to be reported (Stohl, 2004). Rituximab, a chimeric anti-CD20 monoclonal antibody has the ability to deplete B-cells by multiple mechanisms and results are encouraging when it was tried against a variety of autoimmune disorders (Wylam et al., 2003; Ruegg et al., 2004; Stuve et al., 2005).. In extension ocrelizumab, a humanized version of rituximab is currently in the developing stage for targeting several autoimmune disorders (Genovese et al., 2008). The same also holds true for Epratuzumab, a humanised mab that acts by blocking CD22 and 


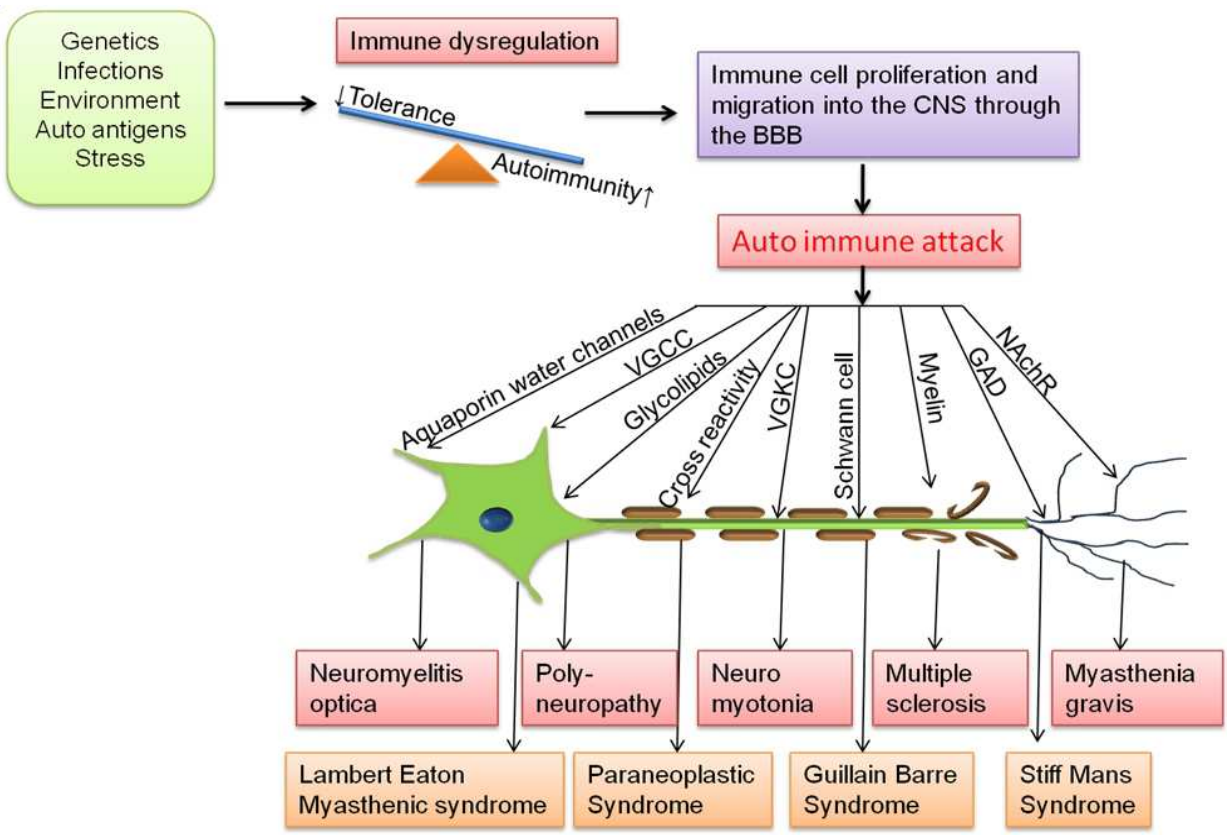

GAD-Glutamicacid decarboxylase; NAchR-Nicotinic acetylcholine receptors; VGCC- Voltage gated calcium channels; VGKC- Voltage gated potassium channels

Fig. 4. Representing the various triggers of autoimmune diseases and the different targets involved in the generation of neurological autoimmune diseases.

thereby depletes B-cell population (Dalakas, 2008). Targeting the T-cell antigens was always an area of intense interest. Researchers have made significant contributions with the development of anti-CD3 MAbs that displayed not only potent immunosuppressive activities but also the ability to restore self tolerance (Chatenoud, 2003). Progress was also presumed with the introduction of T-lymphocyte subsets, the invariant natural killer $\mathrm{T}$ (iNKT) cells. These unique cells stimulate a diverse range of cytokines that regulate the activities of various immune cells and thus prove to be handy for autoimmune disease therapeutics (Gabriel et al., 2010). The preclinical studies of methyl thioadenosine, a natural metabolite was found effective with its immunomodulatory activity in MS model. The results of this study showed an enhanced efficiency when it was combined with interferon's or glatiramer acetate (Moreno et al., 2010). Midkine (MK) a cytokine that binds heparin is generally involved in inflammation by promoting T-cell traffic and cytokine up regulation. The MK inhibitors are assumed to be very valuable for treating MS as an aptamer to MK was found to repress experimental autoimmune encephalitis (Muramatsu, 2011). Histone deacetylase inhibitors were also found to have a potential against MS as they are found to interfere the immune system activation empowered with neuroprotective activities (Faraco et al., 2011). Recent advancements include the application of autologous and allogenic stem cell transplantations following intense immunoablation and the former application has lower toxicities compared to the latter. Encouraging results were obtained in a group of MS patients when treated with autologous stem cells compared to the existing therapies. However, further trials are warranted for the effective use (Marmont, 2000). 


\begin{tabular}{|c|c|c|c|c|}
\hline $\begin{array}{l}\text { S. } \\
\text { No }\end{array}$ & Disorder & \begin{tabular}{|l|}
$\begin{array}{l}\text { Immune attack } \\
\text { directed to }\end{array}$ \\
\end{tabular} & Current therapy & Future drugs \\
\hline 1 & MS & Myelin & $\begin{array}{l}\text { IFNb1a, IFNb1b, } \\
\text { (Clerico et al., 2007) } \\
\text { glatiramer acetate, } \\
\text { (Arnon \& Aharoni, } \\
\text { 2004) } \\
\text { natalizumab, (Polman } \\
\text { et al., 2006) } \\
\text { glucocorticosteroids } \\
\text { (Merck) and } \\
\text { chemotherapeutics } \\
\text { (Chan et al., 2005) }\end{array}$ & $\begin{array}{l}\text { Fingolimod, BG00012, } \\
\text { (Lutterotti \& Berger, 2010) } \\
\text { Laquinimod } \\
\text { Teriflunomide Cladribine } \\
\text { (Yang et al., 2004; Warnke } \\
\text { et al., 2009) } \\
\text { Rituximab } \\
\text { (Hauser et al., 2008) } \\
\text { CAMPATH } \\
\text { (Osborne, 2009) } \\
\text { Midkine } \\
\text { (Muramatsu, 2011) } \\
\text { Methylthio-adenosine } \\
\text { (Moreno et al., 2010) } \\
\text { MAdCAM-1) antibody } \\
\text { (Kanwar et al., 2004) } \\
\text { Histone deacetylase } \\
\text { inhibitors } \\
\text { (Faraco et al., 2011) }\end{array}$ \\
\hline 2 & MG & $\begin{array}{l}\text { Nicotinic } \\
\text { acetylcholine } \\
\text { receptor and } \\
\text { muscle specific } \\
\text { kinase }\end{array}$ & $\begin{array}{l}\text { AchE inhibitors, } \\
\text { (Kumar \& Kaminski, } \\
\text { 2011) } \\
\text { Glucocorticosteroids, } \\
\text { (Hohlfeld et al., 2003) } \\
\text { Azathioprine, (Mertens } \\
\text { et al., 1981). } \\
\text { cyclosporine, (Tindall } \\
\text { et al., 1987) } \\
\text { Cyclophosphamide } \\
\text { and mycophenolate } \\
\text { mofetil (Schneider- } \\
\text { Gold et al., 2006) }\end{array}$ & $\begin{array}{l}\text { SHG2210 } \\
\text { (Keefe et al., 2010) }\end{array}$ \\
\hline 3 & GBS & $\begin{array}{l}\text { Myelin and axonal } \\
\text { membrane in } \\
\text { motor and sensory } \\
\text { fibres }\end{array}$ & $\begin{array}{l}\text { immunomodulatory } \\
\text { therapy with } \\
\text { plasmapheresis and } \\
\text { IVIg (Dalakas, 1999; } \\
\text { Hadden et al., 1998) } \\
\end{array}$ & $\begin{array}{l}\text { Complement inhibitors } \\
\text { (Walgaard et al., 2011) }\end{array}$ \\
\hline 4 & $\mathrm{NMO}$ & $\begin{array}{l}\text { Aquaporin }-4 \\
\text { water channels }\end{array}$ & $\begin{array}{l}\text { interferons, } \\
\text { mycophenolate } \\
\text { mofetil, mitoxantrone } \\
\text { and rituximab } \\
\text { (Bergamaschi, 2007) }\end{array}$ & $\begin{array}{l}\text { Eculizumab } \\
\text { (clinicaltrials.gov) }\end{array}$ \\
\hline
\end{tabular}




\begin{tabular}{|c|c|c|c|c|}
\hline 5 & SMS & $\begin{array}{l}\text { Glutamic acid } \\
\text { decarboxylase } \\
\text { enzyme }\end{array}$ & $\begin{array}{l}\text { skeletal muscle } \\
\text { relaxants, (Duddy \& } \\
\text { Baker, 2009) } \\
\text { Plasmapheresis and } \\
\text { IVIg (Dalakas, 2009; } \\
\text { Hayashi et al., 1999) }\end{array}$ & ------- \\
\hline 6 & PNS & $\begin{array}{l}\text { Hu, Yo,Ma1 \& } \\
\text { Ma2 antibodies }\end{array}$ & $\begin{array}{l}\text { Cyclosporine, } \\
\text { glucocorticoids and } \\
\text { Antithymocyte } \\
\text { globulin (Buchwald et } \\
\text { al., 2005; Koski \& } \\
\text { Patterson, 2006) }\end{array}$ & ------- \\
\hline 7 & LEMS & $\begin{array}{l}\text { Voltage gated } \\
\text { calcium channels }\end{array}$ & $\begin{array}{l}\text { Pyridostigmine } \\
\text { bromide, 3,4- } \\
\text { Diaminopyridine, } \\
\text { guanidine } \mathrm{HCl} \text { and } \\
\text { immunosuppressive } \\
\text { agents (McEvoy et al., } \\
\text { 1989; Sanders, 1995) } \\
\end{array}$ & -------- \\
\hline 8 & NM & $\begin{array}{l}\text { Voltage gated } \mathrm{K}+ \\
\text { channels and } \\
\text { leucine-rich } \\
\text { glioma-inactivated } \\
1 \text { protein }\end{array}$ & $\begin{array}{l}\text { Glucocorticosteroids, } \\
\text { Plasmaoheresis and } \\
\text { IVIg (Merchut, 2010) }\end{array}$ & --.-. \\
\hline 9 & $\mathrm{PN}$ & $\begin{array}{l}\text { Glycolipid GM1 } \\
\text { and myelin } \\
\text { associated } \\
\text { glycoprotein }\end{array}$ & $\begin{array}{l}\text { Glucocorticosteroids, } \\
\text { Plasmapheresis and } \\
\text { IVIg (Shy, 2007) }\end{array}$ & ------- \\
\hline
\end{tabular}

Multiple sclerosis=MS; Myasthenia gravis=MG; Guillain-Barre syndrome=GBS; Neuromyelitis optica=NMO; Stiff-Man syndrome =SMS; Paraneoplastic neurological syndromes=PNS; Lambert-Eaton myasthenic syndrome=LEMS; Neuromyotonia $=\mathrm{NM}$ and Polyneuropathies $=\mathrm{PN}$

Table 1. showing the disease mechanisms, current and future therapeutics for neurological autoimmune diseases.

Targeting the immune cell entry is considered to be an ideal approach and based on this concept we noticed a significant blockade of lymphocyte traffic and eventual recovery in EAE mouse model when administered with mucosal addressin cell adhesion molecule (MAdCAM-1) antibody that binds with the integrins on the lymphocyte cell surface. We also developed a combinatorial approach for this model to protect the neurons against glutamate mediated damage with the a-amino-3-hydroxy-5-methyl-4-isoxazolepropionate (AMPA)/ Kainate receptor antagonist 2,3-dihydroxy -6- nitro-7- sulfamoylbenzo (f)quinoxaline (NBQX), and the N-methyl D-aspartate (NMDA) receptor antagonist GPE(neuro protector glycine-proline-glutamic acid;N-terminal tripeptide of insulin like growth factor ). This combinatorial therapy also helps in reducing the infiltrating immune cells at the site of inflammation in the brain (Kanwar et al, 2004).. We have also patented the treatment of demyelinating diseases by administering GPE (WIPO).In addition, there are 
reports on the highly conserved BARF1 epitopes of Epstein Barr Virus with potent neuroprotective and mitogenic activities (Wynne et al., 2010). We, therefore anticipate conjugating antibodies with such neuroprotectors that would be definitely fruitful for treating a group of neurological autoimmune diseases. Application of nanotechnology also has a tremendous potential for their treatment, as the conjugation of nanoparticles with neuroprotectors and other therapeutics will significantly enhance the targeted delivery, bioavailability and efficacy. Finally introduction of locked nucleic acids (LNAs) has opened a new boom in the area of gene silencing. These LNAs are valuable nucleic acid analogues with striking abilities to regulate gene expression both in vitro and in vivo (Kauppinen et al., 2005). Thus, in the near future they can be suitably modified to control the genetically mediated autoimmune diseases. Table 1 shows the comparison of current and future drugs.

\section{Conclusion}

Further to conclude, the immunosuppressive and anti-inflammatory treatments considered for treating autoimmune diseases pose serious side effects upon long term administration. Hence, it is rather expected, than to hope that emerging therapies based on the advancements made in $\mathrm{T}$ and B-cell targeting would definitely complement or if not replace the existing therapies. It is worth mentioning to find many new novel entities that are in clinical trials for MS and other neurological autoimmune diseases. Inspite of these attractive therapeutic strategies strenuous efforts are to be made to identify the best possible candidates for effective disease control benefiting the patient population.

\section{References}

Allebeck, P., Ahlboom, A., Ljungstrom, K. \& Allander, E. (1984). Do oral contraceptives reduce the incidence of rheumatoid arthritis? Scand.J. Rheumatol, Vol.13, pp. 140146.

Alter, A., Duddy, M., Hebert, S., Biernacki, K., Prat, A. \& Antel, J. P. (2003). Determinants of human B cell migration across brain endothelial cells. J Immunol, Vol.170, pp. 44974505.

Anthony, I.C., Crawford, D.H. \& Bell, J.E. (2003). B lymphocytes in the normal brain: contrasts with HIV-associated lymphoid infiltrates and lymphomas. Brain, Vol.126, pp. 1058-1067.

Arnon, R. \& Aharoni, R. (2004). Mechanism of action of glatiramer acetate in multiple sclerosis and its potential for the development of new applications. Proc Natl Acad Sci USA, Vol.101, Suppl.2, pp. 14593-14598.

Arsura, E., Brunner, N.G., Namba, T. \& Grob, D. (1985). High-dose intravenous methylprednisolone in myasthenia gravis. Arch Neurol, Vol.42, pp. 1149-1153.

Austyn, J.M. (2000). Antigen-presenting Cells Experimental and Clinical Studies of Dendritic Cells. American Journal of Respiratory and Critical Care Medicine, Vol.162, pp.(146150). Axelsson, M., Malmeström, C., Nilsson, S., Haghighi, S., Rosengren, L. \& Lycke, J. (2010). Glial fibrillary acidic protein: a potential biomarker for progression in multiple sclerosis. Journal of Neurology, pp. 1-7.

Bach, J.F. (2002).The effect of infections on susceptibility to autoimmune and allergic diseases. N Engl J Med, Vol.347, pp. 911-920. 
Baker, K.P., Edwards, B.M., Main, S.H., Choi, G.H., Wager, R.E. \& Halpern, W.G. (2003). Generation and characterization of LymphoStat-B, a human monoclonal antibody that antagonizes the bioactivities of B lymphocyte stimulator. Arthritis Rheum, Vol.48, pp. 3253-3265.

Baranzini, S. E., Jeong, M. C., Butunoi, C., Murray, R. S., Bernard, C. C. \& Oksenberg, J. R. (1999). B cell repertoire diversity and clonal expansion in multiple sclerosis brain lesions. J Immunol, Vol.163, pp. 5133-5144.

Baratchi, S., Kanwar, R.K., Cheung, C.H. \& Kanwar, J.R. (2010a). Proliferative and protective effects of SurR9-C84A on differentiated neural cells. J Neuroimmunol, Vol.8, No.227, pp. 120-32.

Baratchi, S., Kanwar, R.K. \& Kanwar, J.R. (2010b). Survivin: a target from brain cancer to neurodegenerative disease. Crit Rev Biochem Mol Biol, Vol.45, No.6, pp. 535-554.

Baratchi, S., Kanwar, R.K. \& Kanwar, J.R. (2011a). Novel survivin mutant protects differentiated SK-N-SH human neuroblastoma cells from activated T-cell neurotoxicity. J Neuroimmunol, Vol.233, No.1-2, pp. 18-28.

Baratchi, S., Kanwar, R.K. \& Kanwar, J.R. (2011b). Survivin mutant protects differentiated dopaminergic SK-N-SH cells against oxidative stress. PLoS One, Vol.10, No.6, pp. e15865.

Barzilai, O., Ram, M. \& Shoenfeld, Y. ( 2007a). Viral infection can induce the production of autoantibodies. Curr Opin Rheumatol, Vol.19, pp. 636-643.

Barzilai, O., Sherer, Y., Ram, M., Izhaky, D.,Anaya, J.M. \& Shoenfeld, Y. (2007b). EpsteinBarr virus and cytomegalovirus in autoimmune diseases: are they truly notorious? A preliminary report. Ann N Y Acad Sci, Vol.1108, pp. 567-577.

Begovich, A.B., Carlton, V.E., Honigberg, L.A., Schrodi, S.J. \& Chokkalingam, A.P. (2004). Amissense singlenucleotide polymorphism in a gene encoding a protein tyrosine phos, phatase (PTPN22) is associated with rheumatoid arthritis. Am. J. Hum. Genet, Vol.75, pp. 330-337.

Bergamaschi, R. (2007).Immune agents for the treatment of Devic's neuromyelitis optica. Neurol Sci, Vol.28, pp. 238-240.

Bottini, N., Musumeci, L., Alonso, A., Rahmouni, S. \& Nika, K. (2004). A functional variant of lymphoid tyrosine phosphatase is associated with type I diabetes. Nat. Genet, Vol.36, pp. 337-338.

Bishop, G.A., Haxhinasto, S.A., Stunz, L.L. \& Hostager, B.S. (2003). Antigen-specific Blymphocyte activation. Crit. Rev. Immunol, Vol.23, pp. 149-197.

Bretscher, P. \& Cohn, M. A. (1970). Theory of self-nonself discrimination. Science, Vol.169, pp. 1042-1049.

Bjorksten, B. (1994). Risk factors in early childhood for the development of allergic disease. Allergy, Vol.49, pp. 400-407.

Bondanza, A., Zimmermann, V.S., Antonio, G.D., Cin, E.D., Balestrieri, G., Tincani, A., Amoura, Z., Piette, J.C., Sabbadini, M.G., Querini, P.R. \& Manfred, A.A. (2004). Requirement of Dying Cells and Environmental Adjuvants for the Induction of Autoimmunity. ARTHRITIS \& RHEUMATISM, Vol.50, No. 5, pp. 1549-1560.

Brosnan, C.F. \& Raine, C.S, (1996). Mechanisms of immune injury in multiple sclerosis. Brain Pathol, Vol.6, pp. 243-257.

Buchwald, B., Ahangari, R., Weishaupt, A. \& Toyka, K.V. (2005). Presynaptic effects of immunoglobulin $\mathrm{G}$ from patients with Lambert-Eaton myasthenic syndrome: their 
neutralization by intravenous immunoglobulins. Muscle Nerve, Vol.31, No.4, pp. 487-494.

Buckley, C. \& Vincent, A. (2005). Autoimmune Channelopathies. Nature Clin Pract Neurol, Vol.1, pp. 22-32.

Bufler, J., Kahlert, S., Tzartos, S., Toyka, K.V., Maelicke, A. \& Franke, C. (1996). Activation and blockade of mouse muscle nicotinic channels by antibodies directed against the binding site of the acetylcholine receptor. J Physiol, Vol.492, pp. 107-114.

Cappione, A., Anolik, J.H., Pugh-Bernard, A., Barnard, J., Dutcher, P., Silverman, G. \& Sanz, I. (2005). Germinal center exclusion of autoreactive B cells is defective in human systemic lupus erythematosus. J. Clin. Invest, Vol.115, pp. 3205-3216.

Carpentier, A.F. \& Delattre, J.Y. (2001). The Lambert-Eaton myasthenic syndrome, Clin Rev Allergy Immunol, Vol.20, pp. 155-158.

Cepok, S., Rosche., Grummel, V., Vogel, F., Zhou, D., Sayn, J., Sommer,N., Hartung, H.P. \& Hemmer, B. (2005). Short-lived plasma blasts are the main B cell effector subset during the course of multiple sclerosis. Brain, Vol.128, pp. 1667-1676.

Chan, A., Weilbach, F.X., Toyka, K.V. \& Gold, R. (2005). Mitoxantrone induces cell death in peripheral blood leucocytes of multiple sclerosis patients. Clin Exp Immunol, Vol.139, pp. 152-158.

Charo, I.F. \& Ransohoff, R.M. (2006). The many roles of chemokines and chemokine receptors in inflammation. N. Engl. J. Med, Vol.354, pp. 610-621.

Chatenoud, L. (2003). CD3-specific antibody-induced active tolerance:from bench to bedside. Nat. Rev. Immunol, Vol.3, pp. 123-132.

Cheung, C.H., Chen, H.H., Cheng, L.T., Lyu, K.W., Kanwar, J.R. \& Chang, J.Y. (2010). Targeting Hsp90 with small molecule inhibitors induces the over-expression of the anti-apoptotic molecule, survivin, in human A549, HONE-1 and HT-29 cancer cells. Mol Cancer, Vol.15, No.9, pp. 77.

Cheung, C.H., Sun, X., Kanwar, J.R., Bai, J.Z., Cheng, L. \& Krissansen, G.W. (2010b). A cellpermeable dominant-negative survivin protein induces apoptosis and sensitizes prostate cancer cells to TNF-a therapy. Cancer Cell Int, Vol.1, No.10, pp. 36.

Clancy, R.M., Backer, C.B., Yin, X., Chang, M.W., Cohen, S.R. \& Lee, L.A. (2004a). Genetic association of cutaneous neonatal lupus with HLA class II and tumor necrosis factor alpha: implications for pathogenesis. Arthritis Rheum, Vol.50, pp. 2598-2603.

Clancy, R.M., Kapur, R.P., Molad, Y., Askanase, A.D. \& Buyon, J.P. (2004b). Immunohistologic evidence supports apoptosis, IgG deposition, and novel macrophage/fibroblast crosstalk in the pathologic cascade leading to congenital heart block. Arthritis Rheum, Vol.50, pp. 173-182.

Clerico, M., Contessa, G. \& Durelli, L. (2007). Interferon-beta1a for the treatment of multiple sclerosis. Expert Opin Biol Ther, Vol.7, No.4, pp. 535-542.

Clifford, D.B., De Luca, A., Simpson, D.M., Arendt, G., Giovannoni, G. \& Nath, A. (2010). Natalizumabassociated progressive multifocal leukoencephalopathy in patients with multiple sclerosis: lessons from 28 cases. Lancet Neurol, Vol.9, pp. 438-446.

Colombo, M., Dono, M., Gazzola, P., Roncella, S., Valetto, A. \& Chiorazzi, N. (2000). Accumulation of clonally related B lymphocytes in the cerebrospinal fluid of multiple sclerosis patients. J Immunol, Vol.164, pp. 2782-2789.

Cooper, G.S., Dooley, M.A., Treadwell, E.L., St Clair, E.W. \& Gilkeson, G.S. (2002). Hormonal and reproductive risk factors for development of systemic lupus 
erythematosus: results of a population-based, casecontrol study. Arthritis Rheum, Vol.46, pp. 1830-1839.

Crow, M.K. (2004). Costimulatory molecules and T-cell-B-cell interactions. Rheum. Dis. Clin. North Am, Vol.30, pp. 175-191.

Cutolo, M. \& Accardo, S. (1991). Sex hormones and rheumatoid arthritis. Clin. Exp. Rheumatol, Vol.9, pp. 641-646.

Cutolo, M. (2003). Solar light effects on onset/relapses and circannual/circadian symptomatology in rheumatoid arthritis. Clin Exp Rheumatol,Vol.21, pp. 148-150.

Czaplinski, \& Steck, A.J. (2004). Immune mediated neuropathies: an update on therapeutic strategies. J Neurol, Vol.251, pp. 127-137.

Dalakas, M.C. \& Quarles, R.H. (1996). Autoimmune ataxic Neuropathies (sensory ganglionopathies): are glycolipids the responsible autoantigens?. Ann Neurol, Vol39, pp. 419-422.

Dalakas, M.C. (1999). Intravenous immunoglobulin in the treatment of autoimmune neuromuscular diseases: present status and practical therapeutic guidelines. Muscle Nerve, Vol.22, No.11, pp. 1479-1497.

Dalakas, M.C., Fujii, M., Li, M. \& McElroy, B. (2000). The clinical spectrum of anti-GAD antibody-positive patients with stiff-person syndrome. Neurology, Vol.55, pp. 15311535.

Dalakas, M.C., Li, M., Fujii, M. \& Jacobowitz, D.M. (2001). Stiff-person syndrome: quantification, specificity and intrathecal synthesis of GAD65 antibodies. Neurology, Vol.57, pp. 780-785.

Dalakas, M.C. (2006). B cells in the pathophysiology of autoimmune neurological disorders: A credible therapeutic target. Pharmacology \& Therapeutics, Vol.112, No.1, pp. 57-70.

Dalakas, M.C. (2008). B cells as therapeutic targets in autoimmune neurological disorders. Nat Clin Pract Neurol, Vol.4, No.10, pp. 557-567.

Dalakas, M.C. (2009). Stiff person syndrome: advances in pathogenesis and therapeutic interventions. Curr Treat Options Neurol, Vol.11, No.2, pp. 102-110.

Dalmau, F., Graus, M.K., Rosenblum, \& Posner, J.B. (1992). Anti-Hu-associated paraneoplastic encephalomyelitis/sensory neuropathy: a clinical study of 71 patients. Medicine (Baltimore), Vol.71, pp. 59-72.

Damian, R.T. (1964). Molecular mimicry: antigen sharing by parasite and host and its consequences. Am. Naturalist, Vol.XCVIII, pp. 129-149.

Darnell, R.B. \& Posner, J.B. (2003). Paraneoplastic syndromes involving the nervous system, N Engl J Med, Vol.349, pp. 1543-1554.

Davidson, A. \& Diamond, B. (2001). Advances in Immunology. N Engl J Med, Vol. 345, No. 5, pp. 340-350.

Dedrick, R.L., Bodary, S. \& Garovoy, M.R. (2003). Adhesion molecules as therapeutic targets for autoimmune diseases and transplant rejection. Expert Opin Biol Ther, Vol.3, No.1, pp. 85-95.

Delves, P.J. (2006). Structural and functional aspects of the innate and adaptive systems of immunity. In: Rose, NR and Mackay, IR, (eds.) The autoimmune diseases. pp. 9-21. Elsevier: San Diego.

Drachman, D.B. (1994). Myasthenia gravis, N Engl J Med, Vol.330, pp. 1797-1810.

Druet, P. (1989). Contributions of immunological reactions to nephrotoxicity. Toxicol Lett, Vol.46 pp. 55-64. 
Duddy, M.E. \& Baker, M.R. (2009). Stiff person syndrome. Front Neurol Neurosci, Vol.26, pp. 147-165.

Fang, C., Zhang, X., Miwa, T. \& Song, W.C. (2009). Complement promotes the development of inflammatory T-helper 17 cells through synergistic interaction with Toll-like receptor signaling and interleukin-6 production. Blood, Vol.114, pp. 1005-1015.

Faraco, G., Cavone, L. \& Chiarugi, A. (2011). The Therapeutic Potential of HDAC Inhibitors in the Treatment of Multiple Sclerosis. Mol Med. Feb 25. [Epub ahead of print].

Fauci, A.S., Wolff, S.M. \& Johnson, J.S. (1971). Effect of cyclophosphamide upon the immune response in Wegener's granulomatosis, N Engl J Med, Vol.285, pp. 1493-1496.

Flickinger, C.J., Baran, M.L., Howards, S.S. \& Herr, J.C. (1994). Epididymal obstruction during development results in antisperm autoantibodies at puberty in rats. $J$ Androl, Vol.19, pp. 136-144.

Fraga, A., Mintz, G. \& Orozco, J. (1974). Sterility and fertility rates, fetal wastage and maternal morbidity in SLE. J. Rheumatol, Vol.1, pp. 293-298.

Frisoni, L., McPhie, L., Colonna, L., Sriram, U., Monestier, M. \& Gallucci, S. (2005). Nuclear autoantigen translocation and autoantibody opsonization lead to increased dendritic cell phagocytosis and presentation of nuclear antigens: a novel pathogenic pathway for autoimmunity? J Immunol, Vol.175, pp. 2692-2701.

Frohman, E.M., Racke, M.K. \& Raine, C.S. (2006). Multiple sclerosis-the plaque and its pathogenesis. N. Engl. J. Med, Vol.354, pp. 942-955.

Fugger, L., Friese, M.A. \& Bell, J.I. (2009). From genes to function: The next challenge to understanding multiple sclerosis. Nat Rev Immunol, Vol.9, No.6, pp. 408-417.

Fujinami, R.S. \& Oldstone, M.B. (1989). Molecular mimicry as a mechanism for virusinduced autoimmunity. Immunol Res, Vol.8, pp. 3-15.

Fujinami, R.S.\& Oldstone, M.B. (1985). Amino acid homology between the encephalitogenic site of myelin basic protein and virus: mechanism for autoimmunity. Science, Vol.230,No.4729, pp. 1043-1045.

Gabriel, C.L., Wu, L., Parekh, V.V. \& Van Kaer, L. (2010). Invariant natural killer t cell-based therapy of autoimmune diseases. Current Immunology Reviews, Vol.6, No.2, pp. 88101.

Gehrs, B.C. \& Friedberg, R.C. (2002). Autoimmune hemolytic anemia. Am J Hematol, Vol.69, pp. 258-271.

Gellert, M. (2002). V(D)J recombination: RAG proteins, repair factors, and regulation. Annu. Rev. Biochem, Vol.71, pp. 101-132.

Genovese, M.C., Kaine, J.L., Lowenstein, M.B., Del Giudice, J., Baldassare, A., Schechtman, J., Fudman, E., Kohen, M., Gujrathi, S., Trapp, R.G., Sweiss, N.J., Spaniolo, G. \& Dummer, W. (2008). Ocrelizumab, a humanized anti-CD20 monoclonal antibody, in the treatment of patients with rheumatoid arthritis: a phase I/II randomized, blinded, placebo-controlled, dose-ranging study. Arthritis Rheum, Vol.58, No.9, pp. 2652-2661.

Gold, R., Dalakas, M.C. \& Toyka, K.V. (2003). Immunotherapy in autoimmune neuromuscular disorders. Lancet Neurol, Vol.2, pp. 22-32.

Gold, R., Linington, C. \& Lassmann, H. (2006). Understanding pathogenesis and therapy of multiple sclerosis via animal models: 70 years of merits and culprits in experimental autoimmune encephalomyelitis research. Brain, Vol.129, pp. 19531971. 
Goldrath, A.W. \& Bevan, M.J. (1999). Selecting and maintaining a diverse T-cell repertoire. Nature, Vol.402, pp. 255-262.

Graus, F., Keime-Guibert, F., Rene, R., Benyahia, B., Ribalta, T. \& Ascaso, C. (2001). Anti$\mathrm{Hu}$-associated paraneoplastic encephalomyelitis: analysis of 200 patients. Brain, Vol.24, pp. 1138-1148.

Green, A.J., McQuaid, S., Hauser, S.L., Allen I.V. \& Lyness, R. (2010). Ocular pathology in multiple sclerosis: retinal atrophy and inflammation irrespective of disease duration, Brain, Vol.133, pp. 1591-1601.

Greter, M., Heppner, F.L., Lemos, M.P., Odermatt, B.M., Goebels, N., Laufer, T., Noelle, R.J. \& Becher, B. (2005). Dendritic cells permit immune invasion of the CNS in an animal model of multiple sclerosis. Nat. Med, Vol.11, pp. 328-334.

Gu, H., Tarlinton, D., Muller, W., Rajewsky, K. \& Forster, I. (1991). Most peripheral B cells in mice are ligand selected. J Exp Med, Vol.173, pp. 1357-1371.

Hadden, R.D., Cornblath, D.R., Hughes RA., Zielasek, J., Hartung, H.P., Toyka, K.V. \& Swan, A.V. (1998). Electrophysiological classification of Guillain-Barre syndrome: clinical associations and outcome. Plasma Exchange/Sandoglobulin Guillain-Barre Syndrome Trial Group. Ann Neurol, Vol.44, No.5, pp. 780-788.

Hafer-Macko, C. E., Sheikh, K. A., Li, C. Y., Ho, T. W., Cornblath, D. R. \& McKhann, G. M.. (1996). Immune attack on the Schwann cell surface in acute inflammatory demyelinating polyneuropathy. Ann Neurol, Vol.39, pp. 625-635.

Hauser, S.L. (2008). Multiple lessons for multiple sclerosis. N Engl J Med, Vol.359, No.17, pp. 1838-1841.

Hauser, S.L., Waubant, E., Arnold, D.L., Vollmer, T., Antel, J., Fox, R.J., Bar-Or, A., Panzara, M., Sarkar, N., Agarwal, S., Langer-Gould, A. \& Smith, C.H. (2008) B-cell depletion with rituximab in relapsing-remitting multiple sclerosis. $N$ Engl J Med, Vol.358, No.7, pp. 676-688.

Hayashi, A., Nakamagoe, K., Ohkoshi, N., Hoshino, S. \& Shoji, S. (1999). Double filtration plasma exchange and immunoadsorption therapy in a case of stiff-man syndrome with negative anti-GAD antibody. J Med, Vol.30, No.(5-6), pp. 321-327.

Heather Rachel Davids, (Mar, 2010), Guillain-Barre Syndrome: Treatment \& Medication In: emedicine,16.03.2011,Available from URL: emedicine.medscape.com/article/315632treatment.

Hennies, C., Sternberg, D., Bistulfi, G.L., Kazim, L., Benedict, R.H.B., Chadha, K., Leung, C., Weinstock-Guttman, B., Munschauer, F. \& Sternberg, Z. (2011). Plasma pentosidine: A potential biomarker in the management of multiple sclerosis. Multiple Sclerosis, Vol.17, No.2, pp. 157-163

Heppner, F.L., Greter, M., Marino, D., Falsig, J., Raivich, G., Hovelmeyer, N., Waisman, A., Rulicke, T., Prinz, M., Priller, J., Becher, B. \& Aguzzi, A. (2005). Experimental autoimmune encephalomyelitis repressed by microglial paralysis. Nat Med, Vol.11, No.2, pp. 146-152.

Herrmann, M., Sholmerich, J. \& Straub, R.H. (2000). Stress and rheumatic disease. Rheum Dis Clin North Am, Vol.26, No.4, pp. 737-763.

Hickey, W. F., Hsu, B. L. \& Kimura, H. (1991). T-lymphocyte entry into the central nervous system. J. Neurosci. Res, Vol.28, pp. 254-260.

Hodgkin, P.D. \& Basten, A.B. (1995). Cell activation, tolerance and antigenpresenting function. Curr Opin Immunol, Vol.7, pp. 121-129. 
Hohlfeld, R., Melms, A., Schneider, C., Toyka, K.V. \& Drachman, D.B. (2003). Therapy of myasthenia gravis and myasthenic syndromes. Brandt, T., Caplan, L.R., Dichgans, J., Diener, H.C. \& Kennard, C. In: Neurological disorders: course and treatment, Elsevier, Stuttgart, pp. 1341-1362.

Holmes, C.H. \& Simpson, K.L. (1992). Complement and pregnancy. New insights into the immunobiology of the feto maternal relationship. Ballières Clin. Obstet. Gynecol,Vol.6, pp.(439-460).

Hooks, J.J., Jordan, G.W., Cupps, T., Moutsopoulos, H.M., Fauci, A.S. \& Notkins, A.L.. (1982). Multiple interferons in the circulation of patients with systemic lupus erythematosus and vasculitis. Arthritis Rheum, Vol.25, pp. 396-400.

Hoyer, B.F., Moser, K., Hauser, A.E., Peddinghaus, A., Voigt, C., Eilat, D., Radbruch, A., Manz, R.A. \& Hiepe, F. (2004). Short-lived plasmablasts and long-lived plasma cells contribute to chronic humoral autoimmunity in NZB/w mice. J. Exp.Med, Vol.199, pp. 1577-1584.

Ishii, A. (2010). Stiff-person syndrome and other myelopathies constitute paraneoplastic neurological syndromes. Brain Nerve, Vol.62, No.4, pp. 377-385.

Jacobson, D.L. (1997). Epidemiology and estimated population burden of selected autoimmune disease in the United States. Clin Immunol Immunopathol, Vol.84, pp. 223-243.

Janeway, C. Jr. \& Travers, P. (1998) Immunobiology. In: The Immune System in Health and Disease, pp 625-640. Garland Publishing Inc, New York Jarow, J.P., Goluboff, E.T., Chang, T.S. \& Marshall, F.F. (1994). Relationship between antisperm antibodies and testicular histologic changes in humans after vasectomy. Urology, Vol.43, pp. 521524 .

Johnson, P.M. (1993). Reproductive and maternofetal relations, In: Gell, P.G.H. \& Coombs, R.R.A, Clinical Aspects of Immunology, Blackwell Johnson, Oxford, pp. 755-767.

Kanwar, J.R., Harrison, J.E.B., Wang, D., Leung, E., Mueller, W., Wagner, N. \& Krissansen, G.W. (1999). $\beta 7$ integrins contribute to demyelinating disease of the central nervous system. Journal of Neuroimmunology, Vol.103, No.2000, pp. 146-152.

Kanwar, J.R., Kanwar, R.K., Wang, D. \& Krissansen, G.W. (2000). Prevention of a chronic progressive form of experimental autoimmune encephalomyelitis by an antibody against mucosal addressin cell adhesion molecule-1, given early in the course of disease progression. Immunology and Cell Biology, Vol.78, pp. 641-645.

Kanwar, R.K., Kanwar, J.R., Wang, D., Ormrod, D.J. \& Krissansen, G.W. (2001). Temporal Expression of Heat Shock Proteins 60 and 70 at Lesion-Prone Sites. Arterioscler Thromb Vasc Biol, Vol.21, pp. 1991-1997.

Kanwar, J.R., Berg, R.W., Yang, Y., Kanwar, R.K., Ching, L.M., Sun, X. \& Krissansen, G.W. (2003). Requirements for ICAM-1 immunogene therapy of lymphoma. Cancer Gene Ther, Vol.10, No.6, pp. 468-476.

Kanwar, J.R., Kanwar, R.K. \& Krissansen, G.W. (2004). Simultaneous neuroprotection and blockade of inflammation reverses autoimmune encephalomyelitis. Brain, Vol.127, No.6, pp. 131313-131331.

Kanwar. J.R. (2005). Anti-inflammatory immunotherapy for multiple sclerosis/experimental autoimmune encephalomyelitis (EAE) disease. Curr Med Chem, Vol.12, No.25, pp. 2947-2962. 
Kanwar, J.R, Kanwar, R.K., Burrow, H. \& Baratchi, S. (2009). Recent advances on the roles of NO in cancer and chronic inflammatory disorders. Curr Med Chem, Vol.16, No.19, pp. 2373-2394.

Kanwar, J.R., Kamalapuram, S.K. \& Kanwar, R.K. (2010a). Targeting survivin in cancer: patent review. Expert Opin Ther Pat, Vol.20, No.12, pp. 1723-37.

Kanwar, J.R, Mahidhara, G. \& Kanwar, R.K. (2010b). MicroRNA in human cancer and chronic inflammatory diseases. Front Biosci (Schol Ed, Vol.1, No.2, pp. 1113-1126.

Kanwar, J.R., Mohan, R.R., Kanwar, R.K., Roy, K. \& Bawa, R. (2010c). Applications of aptamers in nanodelivery systems in cancer, eye and inflammatory diseases. Nanomedicine,Vol.5, No.9, pp. 1435-45.

Kanwar, R.K., Cheung, C.H., Chang, J.Y. \& Kanwar, J.R. (2010d). Recent advances in antisurvivin treatments for cancer. Curr Med Chem, Vol.17, No.15, pp. 1509-1015.

Kappler, J.W., Roehm, N. \& Marrack, P. (1987). T cell tolerance by clonal elimination in the thymus. Cell, Vol.49, pp. 273-280.

Kauppinen, S., Vester, B. \& Wengel, J. (2005). Locked nucleic acid (LNA): High affinity targeting of Complementary RNA for diagnostics and therapeutics. Drug Discovery Today: Technol, Vol.2, pp. 287.

Keefe, D., Parng, C., Lundberg, D., Ray, S., Martineau-Bosco, J., Leng, C., Tzartos, S., Powell, J., Concino, M., Heartlein, M., Lamsa, J. \& Josiah, S. (2010). In vitro characterization of an acetylcholine receptor-transferrin fusion protein for the treatment of myasthenia gravis. Autoimmunity, Vol.43, No.8, pp. 628-639.

Khamashta, M.A., Ruiz-Irastorza, G. \& Hughes, G.R. (1997). Systemic lupus erythematosus flares during pregnancy. Rheum. Dis. Clin. N. Am, Vol.23, pp. 15-30.

Kieseier, B.C., Kiefer, R., Gold, R., Hemmer, B., Willison, H.J. \& Hartung, H. P. (2004). Advances in understanding and treatment of immune-mediated disorders of the peripheral nervous system. Muscle Nerve, Vol.30, pp. 131-156.

Kleopas, A.K., Elman, L.B., Lang, B., Vincent, A. \& Scherer, S.S. (2006). Neuromyotonia and limbic encephalitis sera target mature Shaker-type K+ channels: subunit specificity correlates with clinical manifestations. Brain, Vol.129, pp. 1570-1584.

Knopf, P. M., Harling-Berg, C. J., Cserr, H. F., Basu, D., Sirulnick, E. J. \& Nolan, S. C. (1998). Antigen-dependent intrathecal antibody synthesis in the normal rat brain: tissue entry and local retention of antigen-specific B cells. J Immunol, Vol.161, pp. 692-701.

Kornberg, A.J. \& Pestronk, A. (2003). Antibody-associated polyneuropathy syndromes: principles and treatment. Semin Neurol, Vol.23, pp. 181-190.

Koski, C.L. \& Patterson, J.V. (2006). Intravenous immunoglobulin use for neurologic diseases. J Infus Nurs, Vol.29, Suppl.3, pp. S21-8.

Kumar, V. \& Kaminski, H.J. (2011). Treatment of Myasthenia Gravis. Curr Neurol Neurosci Rep, Vol.11, pp. 89-96.

Kuwabara, S. (2004). Guillain-Barré syndrome: epidemiology, pathophysiology and management. Drugs, Vol.64, pp. 597-610.

Lai, M., Huijbers, M.G.M., Lancaster, E., Graus, F., Bataller, L., Balice-Gordon, R., Cowell, J.K. \& Dalmau, J. (2010). Investigation of LGI1 as the antigen in limbic encephalitis previously attributed to potassium channels: A case series The Lancet Neurology, Vol.9, No.8, pp. 776-785.

Lambert-Eaton syndrome, In: PubMed Health,09.03.2011,Available from URL: www.ncbi.nlm.nih.gov/pubmedhealth/PMH0001729/. 
Lennon, V.A., Kryzer, T.J., Pittock, S.J., Verkman A.S. \& Hinson, S.R. (2005). IgG marker of optic-spinal multiple sclerosis binds to the aquaporin-4 water channel, J Exp Med, Vol.202, pp. 473-477.

Leung, E., Kanwar, R.K., Kanwar, J.R. \& Krissansen, G.W. (2003). Mucosal vascular addressin cell adhesion molecule- 1 is expressed outside the endothelial lineage on fibroblasts and melanoma cells. Immunol Cell Biol, Vol.81, No.4, pp. 320-327.

Lim, K.J.H., Odukoya, O.A. \& Ajjan, R.A. (1998). Profile of cytokine mRNA expression in peri-implantation human endometrium. Mol.Hum. Reprod, Vol.4, pp. 77-81.

Lleo, A., Invernizzi, P., Gao, B., Podda, M. \& Gershwin, M.E. (2010). Definition of human autoimmunity - autoantibodies versus autoimmune disease. Autoimmunity Reviews, Vol.9, pp. 259-266.

Lucchinetti, C., Bruck, W., Parisi, J., Scheithauer, B., Rodriguez, M. \& Lassmann, H. (2000). Heterogeneity of multiple sclerosis lesions: implications for the pathogenesis of demyelination. Ann Neurol, Vol.47, pp. 707-717.

Lucchinetti, C.F., Mandler, R.N., McGavern, D., Bruck, W., Gleich, G. \& Ransohoff R.M. (2002). A role for humoral mechanisms in the pathogenesis of Devic's neuromyelitis optica, Brain, Vol.125, pp. 1450-1461.

Lutterotti, A. \& Berger, T. (2010). Advances in Multiple Sclerosis Therapy: New Oral Disease-Modifying Agents, CML - Multiple Sclerosis, Vol.2, No.1, pp. 1-10.

Mackay, C. R., Marston, W. L. \& Dudler, L. (1990). Naive and memory T cells show distinct pathways of lymphocyte recirculation. J. Exp. Med, Vol. 171, No.3, pp. 801-817. Mackay, R. \& Rosen, F.S. (2001). Autoimmune Diseases. N Engl J Med, Vol.345, pp. 340-350.

Manoury, B, Hewitt, E.W, Morrice, N, Dando, P.M, Barrett, A.J. \& Watts, C. (1998). An asparaginyl endopeptidase processes a microbial antigen for class II MHC presentation. Nature, Vol.396, pp. 695-699.

Manz, R.A., Thiel, A. \& Radbruch, A. (1997). Lifetime of plasma cells in the bone marrow.Nature, Vol.388, pp. 133-134.

Manz, R.A., Löhning, M., Cassese, G., Thiel, A. \& Radbruch, A. (1998). Survival of longlived plasma cells is independent of antigen. Int. Immunol, Vol.10, pp. 1703-1711.

Manz, R.A., Hauser, A.E., Hiepe, F. \& Radbruch, A. (2005). Maintenance of serum antibody levels. Annu. Rev. Immunol, Vol.23, pp. 367-386.

Marmont, A.M. (2000). New horizons in the treatment of autoimmune diseases: immunoablation and stem cell transplantation. Annu Rev Med, Vol.51, pp. 115-134.

Maverakis, E., Goodarzi, H., Wehrli, L.N., Ono, Y. \& Garcia, M.S. (2011). The Etiology of Paraneoplastic Autoimmunity. Clin Rev Allergy Immunol, Jan 19 [Epub ahead of print].

MayoClinic, Multiple Sclerosis, 25.02.2011, Available from URL: www.mayoclinic.org/multiple-sclerosis/

McEvoy, K.M., Windebank, A.J., Daube, J.R. E Low, PA. (1989). 3,4-Diaminopyridine in the treatment of Lambert-Eaton myasthenic syndrome. N Engl J Med, Vol.321, No.23, pp. 1567-1571.

McKall-Faienza, K.J., Kawai, K., Kundig, T.M., Odermatt, B., Bachmann, M.F., Zakarian, A., Mak, T.W. \& Ohashi, P.S. (1998). Absence of TNFRp55 influences virus-induced autoimmunity despite efficient lymphocytic infiltration. Int Immunol, Vol.10, pp. 405-412. 
McMurray, R.W. (1996). Adhesion molecules in autoimmune disease. Semin Arthritis Rheum, Vol.25, No.4, pp. 215-33.

Merchut, M.P. (2010). Management of voltage-gated potassium channel antibody disorders. Neurologic Clinics, Vol.28, No.4, pp. 941-959.

Merck, Multiple Sclerosis (MS), 27.02.2011, Available from URL: www.merckmanuals.com/home/sec06/ch092/ch092b.html

Mertens, H.G., Hertel, G., Reuther, P. \& Ricker, K. (1981). Effect of immunosuppressive drugs (azathioprine). Ann NY Acad Sci, Vol.377, pp. 691-699.

Monroe, J.G., Bannish, G., Fuentes-Panana, E.M., King, L.B., Sandel, P.C., Chung, J. \& Sater, R. (2003). Positive and negative selection during B lymphocyte development. Immunol. Res, Vol.27, pp. 427-442.

Moreno, B., Fernandez-Diez, B., Di Penta, A. \& Villoslada, P. (2010). Preclinical studies of methylthioadenosine for the treatment of multiple sclerosis. Mult Scler, Vol.16, No.9, pp. 1102-1108.

Muramatsu, T. (2011). Midkine: a Promising Molecule for Drug Development to Treat Diseases of the Central Nervous System. Curr Pharm Des, Mar 4. [Epub ahead of print]. Multiple Sclerosis Treatments, 27.02.2011, Available from URL: www.multsclerosis.org/mstreatments.html Nobile-Orazio, E. (2001). Multifocal motor neuropathy. J Neuroimmunol, Vol.115, pp. 4-18.

Latov, N. (1994). Antibodies to glycoconjugates in neuropathy and motor neuron disease. Prog Brain Res, Vol.101, pp. 295-303.

Ogawara, K., Kuwabara, S., Mori, M., Hattori, T., Koga, M. \& Yuki, N. (2000). Axonal Guillain-Barré syndrome: relation to anti-ganglioside antibodies and Campylobacter jejuni infection in Japan. Ann Neurol, Vol.48, pp. 624-631.

Ohishi, K., Kanoh, M., Shinomiya, H., Hitsumoto, Y. \& Utsumi, S. (1995). Complement activation by cross-linked B cell-membrane IgM. J Immunol, Vol.154, pp. 3173-3179.

Oldstone, M.B.A. (1998). Molecular mimicry and immune-mediated diseases. FASEB J, Vol.12, pp. 1255-1265.

Osborne, R. (2009). Buzz around Campath proof-of-concept trial in MS. Nat Biotechnol, Vol.27, No.1, pp. 6-8.

Palmer, E. (2003). Negative selection - clearing out the bad apples from the T-cell repertoire. Nat. Rev. Immunol, Vol.3, pp. 383-391.

Patterson, C.C., Carson, D.J. \& Hadden, D.R. (1996). Epidemiology of childhood IDDM in Northern Ireland 1989e1994: low incidence in areas with highest population density and most household crowding. Diabetologia, Vol.39, pp. 1063-1069.

Pender, M.P. (1995). An introduction to neuroimmunology, In: Autoimmune neurological diseases,Pender, M.P \& McCombe, P.A, pp.16. cambridge university press.

Peterson, K., Rosenblum, M.K., Kotanides, H. \& Posner, J.B. (1992). Paraneoplastic cerebellar degeneration: I. A clinical analysis of 55 anti-Yo antibody positive patients, Neurology, Vol.42, pp. 1931-1937.

Pettinelli, C.B. \& McFarlin, D.E. (1981). Adoptive transfer of experimental allergic encephalomyelitis in SJL/J mice after in vivo activation of lymph node cells by myelin basic protein: requirement for Lyt-1+2- T lymphocytes. J Immunol, Vol.127, pp. 1420-1423. 
Pircher, H., Rohrer, H.U., Moskophidis, D., Zinkernagel, R.M. \& Hengartner, H. (1991). Lower receptor avidity required for thymic clonal deletion than for effector $\mathrm{T}$ cell function. Nature, Vol.351, pp. 482-485.

Polman, C.H., O'Connor, P.W., Havrdova, E., Hutchinson, M., Kappos, L. \& Miller, D.H. (2006). A randomized, placebo-controlled trial of natalizumab for relapsing multiple sclerosis. N Engl J Med, Vol.354, pp. 899-910.

Pranzatelli, M.R., Travelstead, A.L., Tate, E.D., Allison, T.J., Moticka, E.J., Franz, D.N., Nigro, M.A., Parke, J.T., Stumpf, D.A. \& Verhulst, S.J. (2004). B- and T-cell markers in opsoclonus-myoclonus syndrome: immunophenotyping of CSF lymphocytes, Neurology, Vol.62, pp. 1526-1532.

Qin, Y., Duquette, P., Zhang, Y., Talbot, P., Poole, R. \& Antel, J. (1998). Clonal expansion and somatic hypermutation of $\mathrm{VH}$ genes of $\mathrm{B}$ cells from cerebrospinal fluid in multiple sclerosis. J Clin Invest, Vol.102, pp. 1045-1050.

Quarles, R.H. \& Weiss, M.D. (1999). Autoantibodies associated with peripheral neuropathy. Muscle Nerve, Vol.22, pp. 800-822.

Racke, M.K \& Stuart, R.W. (2002). Targeting T cell costimulation in autoimmune disease. Expert Opin Ther Targets, Vol.6, No.3, pp. 275-89.

Radbruch, A., Muehlinghaus, G., Luger, E.O., Inamine, A., Smith, K.G., Dörner, T. \& Hiepe, F. (2006). Competence and competition: the challenge of becoming a long-lived plasma cell. Nat. Rev. Immunol, Vol.6, pp. 741-750.

Ragheb. \& Lisak, R.P. (1998). Immune regulation and myasthenia gravis. Ann N Y Acad Sci, Vol.841, pp. 210-224.

Raghupathy, R. (1997). Th-1 type immunity is incompatible with successful pregnancy. Immunol. Today, Vol.18, pp. 478-482.

Rajewsky, K. (1996). Clonal selection and learning in the antibody system. Nature, Vol.381, pp.(751-758).

Rodien, P., Madec, A.M., Ruf, J., Rajas, F., Bornet, H. \& Carayon, P. (1996). Antibodydependent cell-mediated cytotoxicity in autoimmune thyroid disease: relationship to antithyroperoxidase antibodies. J Clin Endocrinol Metab, Vol.81, pp. 2595-2600.

Roitt, I, Brostoff, J \& Male, D. (1998). Immunology, Mosby, London UK, pp. 410- 425.

Rosenfeld, M.R., Eichen, J.G., Wade, D.F., Posner, J.B. \& Dalmau, J. (2001). Molecular and clinical diversity in Paraneoplastic immunity to Ma proteins. Ann Neurol, Vol.50, pp. 339-348.

Ross, R. (1990). Mechanisms of atherosclerosis-a review. Adv Nephrol Necker Hosp,Vol.19, pp.79-86.

Galperin, C \& Gershwin, ME. (1997). Immunopathogenesis of gastrointestinal and hepatobiliary diseases. JAMA,Vol.278, pp. 1946-1955.

Roubinian, J.R., Talal, N., Greenspan, J.S., Goodman, J.R. \& Siiteri, P.K. (1978).Effect of castration and sex hormone treatment on survival,anti-nucleic acid antibodies, and glomerulonephritis in NZB/NZW F1 mice. J Exp Med, Vol.147, pp. 1568-1583.

Ruegg, S.J., Fuhr, P. \& Steck, A.J. (2004). Rituximab stabilizes multifocal motor neuropathy increasingly less responsive to IVIg. Neurology, Vol.63, pp. 2178-2179.

Sakic, B., Szechtman, H., Denburg, J.A., Gomy, G., Kolb, B. \& Whishaw IQ. (1998).Progressive atrophy of pyramidal neuron dendrites in autoimmune MRL/lpr mice. J Neuroimmunol, Vol.87, pp. 162-170. 
Sanders, D.B. (1995). Lambert-Eaton myasthenic syndrome: clinical diagnosis, immunemediated mechanisms, and update on therapies. Ann Neurol, Vol.37, Suppl 1, pp. 63-73.

Schattner, A. (1994). Lymphokines in autoimmunity-a critical review. Clin Immunol Immunopathol, Vol.70, pp. 177-189.

Schneider-Gold, C., Hartung, H.P. \& Gold, R. (2006). Mycophenolate mofetil and tacrolimus: New therapeutic options in neuroimmunological diseases. Muscle E Nerve, Vol.34, pp.284-291.

Shy, M.E. (2007). Peripheral neuropathies, Goldman L, Ausiello D. In: Cecil Medicine, Elsevier, Philadelphia, Pa: Saunders, pp.446.

Silverstein, A.M. \& Rose, N.R. (2000).There is only one immune system! The view from immunopathology. Semin Immunol, Vol.12, No.173, No.8, pp. 257-344.

Singer, P.A. \& Theofilopoulos, A.N. (1990).T cell receptor V) repertoire expression in murine models of SLE. Immunol Rev, Vol.118, pp. 103-127.

Slifka, M.K., Antia, R., whitmire, J.K. \& Ahmed, R. (1998). Humoral immunity due to longlived plasma cells. Immunity, Vol.8, pp. 363-372.

Smith, D.A. \& Dori, R. (1999). Introduction to Immunology and Autoimmunity. Environmental Health Perspectives, Vol.107, Supplement. 5, pp. 661-665.

Starr, T.K., Jameson, S.C. \& Hogquist, K.A. (2003). Positive and negative selection of T cells. Annu. Rev. Immunol, Vol.21, pp. 139-176.

Steinman, L. (2002). A few autoreactive cells in an autoimmune infiltrate control a vast population of nonspecific cells: a tale of smart bombs and the infantry. Proc. Natl. Acad. Sci. U. S. A, Vol.93, pp. 2253-2256.

Stohl, S.W. (2004). Targeting B lymphocyte stimulator in systemic lupus erythematosus and other autoimmune rheumatic disorders. Expert Opin Ther Targets, Vol.8, pp. 177189.

Stojanovich, L. \& Marisavljevich, D. (2008). Stress as a trigger of autoimmune disease Autoimmun Rev, Vol.7, No.3, pp. 209-213.

Stuve, O., Cepok, S., Elias, S., Saleh, A., Hartung, H.P., Hemmer, B. E Kieseier, B.C. (2005). Clinical stabilization and effective bB-lymphocyte depletion in the cerebrospinal fluid and peripheral blood of a patient with fulminant relapsing-remitting multiple sclerosis, Arch Neurol, Vol.62, pp. 1620-1623.

Swain, S.L. (2003). Regulation of the generation and maintenance of T-cell memory: a direct, default pathway from effectors to memory cells. Microbes. Infect, Vol.5, pp. 213-219

Tan, M.E., Reimer, G. \& sullivan, K.(1987).Itracellularv antigens:diagnostic fingerprints but aetiological dilemmas, Evered, D \& Whelan, J. In: autoimmunity and autoimmune disease. John Wiley \& Sons Ltd, Chichester,UK, pp. 25-30.

Tarlinton, D., Radbruch, A., Hiepe, F. \& Dörner, T. (2008). Plasma cell differentiation and survival. Curr.Opin. Immunol, Vol.20, pp. 162-169.

Tindall, R.S., Rollins, J.A., Phillips, J.T., Greenlee, R.G., Wells, L. \& Belendiuk, G. (1987). Preliminary results of a double-blind, randomized, placebo-controlled trial of cyclosporine in myasthenia gravis. N Engl J Med, Vol.316, pp. 719-724.

Trembleau, S., Germann, T., Gately, M.K. Z. \& Adorini, L. (1995).The role of IL-12 in the induction of organ-specific autoimmune diseases. Immunol Today, Vol.16, pp. 383386. 
Vandiedonck, C., Capdevielle, C., Giraud, M., Krumeich, S. \& Jais, J.P. (2006). Association of the PTPN22*R620W polymorphism with autoimmune myasthenia gravis. Ann. Neuro, .Vol.59, pp. 404-407.

VanVoorhis, B.J. \& Stovall, D.W. (1997). Autoantibodies and fertility: a review of the literature. J. Reprod. Immunol.Vol.33, pp. 239-256.

Vincent, A., Beeson, D. \& Lang, B. (2000). Molecular targets for autoimmune and genetic disorders of neuromuscular transmission. Eur J Biochem, Vol.267, pp. 6717-6728.

Vincent, A., Bowen, J., Newsom-Davis, J. \& McConville, J. (2003). Seronegative generalised myasthenia gravis: clinical features, antibodies and their targets. Lancet Neurol, Vol.2, pp. 99-106.

Vogt, M.H., Lopatinskaya, L., Smits, M., Polman, C.H. \& Nagelkerken, L. (2003). Elevated osteopontin levels in active relapsing-remitting multiple sclerosis. Ann Neurol, Vol.53, No.6, pp. 819-822.

Waldor, M.K., Sriram, S., Hardy, R., Herzenberg, L.A., Herzenberg, L.A., Lanier, L., Lim, M. \& Steinman, L. (1985). Reversal of experimental allergic encephalomyelitis with a monoclonal antibody to a T cell subset marker (L3T4). Science, Vol.15, pp. 417

Walgaard, C., Jacobs, B.C. \& Van Doorn, P.A. (2011). Emerging drugs for Guillain-Barr? Syndrome. Expert Opin Emerg Drugs, Vol.16, No.1, pp. 105-120.

Warnke, C., Meyer, H.G., Hartung, H.P., Stuve, O. \& Kieseier, B.C. (2009). Review of teriflunomide and its potential in the treatment of multiple sclerosis. Neuropsychiatr Dis Treat, Vol.5, pp. 333-340.

Webster, E.L., Torpy, D.J., Elenkov, I.J. \& Chrousos, G.P. (1998). Corticotropinreleasing hormone and inflammation. Ann NY Acad Sci, Vol.840, pp. 21-32.

Wekerle, H., Linington, C., Lassmann, H. \& Meyermann, R, (1986). Cellular immune reactivity within the CNS. Trends Neurosci, Vol.9, pp. 271-277.

Whitaker, J.N. (1987). The presence of immunoreactive myelin basic protein peptide in urine of persons with multiple sclerosis. Ann Neurol, Vol.22, No.5, pp. 648-655.

Willison, H. J. \& Yuki, N. (2002). Peripheral neuropathies and anti-glycolipid antibodies. Brain, Vol.125, pp. 2591-2625.

Wingerchuk, D.M. (2004). Neuromyelitis optica: current concepts, Front Biosci, Vol.9, pp. 834-840.

WIPO, 28.03.2011, Available from URL:

www.wipo.int/pctdb/en/fetch.jsp?LANG=ENG\&DBSELECT=PCT\&SERVER_TY $\mathrm{PE}=19-10 \& S O R T=11316447-$

KEY\&TYPE_FIELD $=256 \& I D B=0 \& I D O C=1324445 \& C=10 \& E L E M E N T \_S E T=B \& R E S$

$\mathrm{ULT}=5 \& \mathrm{TOTAL}=7 \& S T A R T=1 \& \mathrm{DISP}=25 \& \mathrm{FORM}=\mathrm{SEP}-0 / \mathrm{HITNUM}, \mathrm{B}-$

ENG,DP,MC,AN,PA,ABSUM-

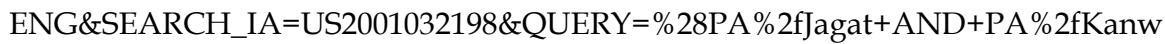
$\operatorname{ar} \% 29+]$

Wylam, M.E., Anderson, P.M., Kuntz, N.L. \& Rodriguez, V. (2003). Successful treatment of refractory myasthenia gravis using rituximab: a pediatric case report. I Pediatr, Vol.143, pp. 674-677.

Wynne, A., Kanwar, R.K., Khanna, R. \& Kanwar, J.R. (2010). Recent Advances on the Possible Neuroprotective Activities of Epstein- Barr Virus Oncogene BARF1 Protein in Chronic Inflammatory Disorders of Central Nervous System. Current Neuropharmacology, Vol.8, pp. 268-275. 
Yagi, J. \& Janeway, C.A. (1990). Ligand thresholds at different stages of T cell development. Int. Immunol, Vol.2, pp. 83-89.

Yan, W.X., Taylor, J., Andrias-Kauba, S. \& Pollard, J.D. (2000). Passive transfer of demyelination by serum or IgG from chronic inflammatory demyelinating polyneuropathy patients. Ann Neurol, Vol.47, pp. 765-775.

Yang, J.S., Xu, L.Y., Xiao, B.G., Hedlund, G. \& Link, H. (2004). Laquinimod (ABR-215062) suppresses the development of experimental autoimmune encephalomyelitis, modulates the Th1/Th2 balance and induces the Th3 cytokine TGF-beta in Lewis rats. J Neuroimmunol, Vol.56, pp. 3-9.

Yang, Y. \& Santamaria, P. (2006). T cells and autoimmunity. In: Rose, N.R. \& Mackay, I.R. The Autoimmune Diseases, Elsevier Academic Press, San Diego, pp. 59-82.

Yoon, J.W., Austin, M., Onodera, T. \& Notkins, A.L. (1979).Virus-induced diabetes mellitus. Isolation of a virus from the pancreas of a child with diabetic ketoacidosis. $N$ EngI J Med, Vol.300, pp. 1173-1179

Yoshida, S. \& Gershwin M.E. (1993). Autoimmunity and selected environmental factors of disease induction. Semin Arthritis Rheum, Vol.22, pp. 399-419.

Ziff, M. (1991). Role of the endothelium in chronic inflammatory synovitis. Arthritis Rheum, Vol.34, pp. 1345-1352.

Zinman, L., Ng, E. \& Bril, V. (2007). IV immunoglobulin in patients with myasthenia gravis A randomized controlled trial. Neurology, Vol.68, pp. 837-841.

An Open Label Study of the Effects of Eculizumab in Neuromyelitis Optica, In: clinical trials.gov, 7.03.2011, Available from URL:

clinicaltrials.gov/ct2/show/NCT00904826 


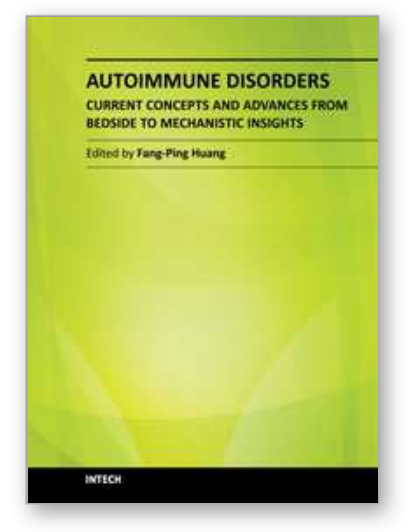

\author{
Autoimmune Disorders - Current Concepts and Advances from \\ Bedside to Mechanistic Insights \\ Edited by Dr. Fang-Ping Huang
}

ISBN 978-953-307-653-9

Hard cover, 614 pages

Publisher InTech

Published online 14, November, 2011

Published in print edition November, 2011

Autoimmune disorders are caused due to break down of the immune system, which consequently fails in its ability to differentiate "self" from "non-self" in the context of immunology. The diseases are intriguing, both clinically and immunologically, for their diversified clinical phenotypes and complex underlying immunological mechanisms. This book offers cutting-edge information on some of the specific autoimmune disease phenotypes, respective diagnostic and prognostic measures, classical and new therapeutic options currently available, pathogenesis and underlying mechanisms potentially involved, and beyond. In the form of Open Access, such information is made freely available to clinicians, basic scientists and many others who will be interested regarding current advances in the areas. Its potential readers will find many of the chapters containing in-depth analysis, interesting discussions and various thought-provoking novel ideas.

\title{
How to reference
}

In order to correctly reference this scholarly work, feel free to copy and paste the following:

Jagat R. Kanwar, Bhasker Sriramoju and Rupinder K. Kanwar (2011). Recent Advances in the Treatment of Neurological Autoimmune Disorders, Autoimmune Disorders - Current Concepts and Advances from Bedside to Mechanistic Insights, Dr. Fang-Ping Huang (Ed.), ISBN: 978-953-307-653-9, InTech, Available from: http://www.intechopen.com/books/autoimmune-disorders-current-concepts-and-advances-from-bedside-tomechanistic-insights/recent-advances-in-the-treatment-of-neurological-autoimmune-disorders

\section{INTECH}

open science | open minds

\author{
InTech Europe \\ University Campus STeP Ri \\ Slavka Krautzeka 83/A \\ 51000 Rijeka, Croatia \\ Phone: +385 (51) 770447 \\ Fax: +385 (51) 686166 \\ www.intechopen.com
}

\author{
InTech China \\ Unit 405, Office Block, Hotel Equatorial Shanghai \\ No.65, Yan An Road (West), Shanghai, 200040, China \\ 中国上海市延安西路65号上海国际贵都大饭店办公楼 405 单元 \\ Phone: +86-21-62489820 \\ Fax: $+86-21-62489821$
}


(C) 2011 The Author(s). Licensee IntechOpen. This is an open access article distributed under the terms of the Creative Commons Attribution 3.0 License, which permits unrestricted use, distribution, and reproduction in any medium, provided the original work is properly cited. 